\title{
AS FONTES DA NOVA LEX MERCATORIA: O INÍCIO DE UMA NOVA ALQUIMIA REFLEXIVA - MÉTODOS E REFLEXOS; FLUXOS E IMPULSOS
}

Ricardo Alexandre Cardoso Rodrigues

ISSUE DOI: $10.21207 / 1983.4225 .307$

\section{RESUMO}

Temos assistido, nos últimos anos, a diversas manifestações da Nova Ordem Mundial, seja no plano político, social, econômico e financeiro.

A nova lex mercatoria representa a melhor expressão destas mutações no comércio transnacional, pela sua natureza transnacional, dinâmica, revela-se intensamente multifacetada, pelo que constitui uma realidade jurídica open-ended ou in progress.

Neste estudo, procuramos desenvolver, cientificamente, aquilo a que chamamos, no plano das fontes, o núcleo duro da nova lex mercatoria, os seus diversos afloramentos e desenvolvimentos no curso da história.

O objetivo fundamental desta investigação é através de um processo de sistematização permitir aos juristas e interessados nestes assuntos um acesso simplificado para uma profunda compreensão da sua natureza e amplitude. 
Palavras chave: Nova lex mercatória. Comércio transnacional. Fontes do Direito.

\section{INTRODUÇÃO}

A globalização e a mundialização transmutaram, definitivamente, a sociedade e o globo. A realidade econômica hodierna já não se compadece com a rigidez, obscuridade, entre outras limitações próprias dos direitos Estaduais.

A dinâmica das operações mercantis num espaço tão fluído como o transnacional, a par dos riscos inerentes aos grandes investimentos, pressupõe, necessariamente, uma elevada segurança jurídica.

As expetativas dos operadores do mercado não poderão ser frustradas, razões de ordem econômica, social, política e até cultural, motivam uma tutela eficiente aos interesses e necessidades do comércio transnacional.

A nova lex mercatoria enquanto verdadeira ordem jurídica dispõe dos instrumentos fundamentais à otimização das transações, com reflexo econômico e financeiro imediato.

Constitui o instrumento mais eficiente para a contratação internacional, seja enquanto corpo disciplinador por via direta, como estrutura normativa a que se chegue pela via indireta, ou como ordenamento jurídico coadjuvante. A nova lex mercatoria constitui o marco ideal da nova ordem econômica transnacional.

Foi através da lex mercatoria - nos seus diferentes estádios evolutivos - que os operadores de mercado viram singrar as respetivas atividades comerciais no seio do seu setor de mercado.

$\mathrm{Na}$ antiguidade, passando pela Idade Média, pelo fim da Idade Moderna, pela Idade Contemporânea, a lex mercatoria provou a adaptabilidade e flexibilidade funcionais - à realidade espacial e temporal - que tanto a carateriza.

A lex mercatoria remonta à Antiguidade, revelando-se, como estrutura autossuficiente em meados do século X-XI. Emergindo como ius mercatorum - essencialmente pelas fragilidades do Direito do Império Romano desagregado e das insuficiências dos Direitos feudais -, o Direito dos mercadores e o Direito das suas corporações, com uma natureza 
jurídica espontânea, tendo por base os usos e costumes do comércio local e internacional, regras de conduta (etc.), atingira a sua fase adulta no final da Idade Média.

Com o surgimento do Estado soberano, aparecem as primeiras codificações que absorveram para os seus dispositivos legais os normativos do direito dos mercadores, passando a aplicar-se como Direito Estadual. A partir dos séculos XVII e XVIII, uma nova fase daquele Direito toma lugar.

Veem-se renascidas as suas formas e o seu conteúdo exponencialmente mais vasto, mas também, mais coeso, mais sistemático.

Os contornos dessa realidade ganham uma dimensão verdadeiramente internacional ou transnacional por efeito da globalização e mundialização hodiernas.

Para essa unicidade muito contribuíram os dois instrumentos de soft law mais marcantes no panorama do Direito comercial internacional: os princípios UNIDROIT e os princípios LANDO ${ }^{201} 202$.

Com uma natureza não vinculativa, o Direito comercial internacional recorreu a um jogo de influência, utilizando modelos de regulação, mas também, modelos interpretativos e integrativos, servindo como fonte de inspiração para legisladores, julgadores e intérpretes.

A nova lex mercatoria ou new law merchant corresponde a um novo corpo normativo bastante amplo no que tange ao seu conteúdo, compreendendo: usos e costumes, modelos jurídicos: contratos tipo e formulários standard, contratos auto-normativos, contratos atípicos (sobretudo os tipos sociais), jurisprudência, princípios gerais do direito e, em especial, os princípios gerais em matéria contratual; por último, direito harmonizado, unificado e uniforme da contratação internacional.

Apresenta-se como uma realidade dinâmica, multidimensional, uma ordem jurídica suis generis. ${ }^{203,204}$. Opinião fervorosamente combatida e apaixonadamente acolhida por diversos setores de opinião ${ }^{205}$.

\footnotetext{
${ }^{201}$ De notar, as potencialidades destes últimos princípios, seja como base para um futuro código europeu dos contratos seja para a edificação de uma verdadeira "infraestrutura" para a legislação, em matéria contratual, da União Europeia. Aliás, o reflexo dessa evolução está na criação de um Quadro Europeu Comum de Referência em matéria de contratos (QFR).

202 Marcos aos quais dedicaremos especial atenção.

${ }^{203}$ Partindo duma perspetiva sociológica do direito nos seus axiomas estruturais definimos

- in Regulação apositiva da contratação internacional - New law merchant, in pas-
} 
Constitui uma realidade ampla, desenvolta, fluida, deveras eficiente, adequada às exigências do comércio transnacional. Um direito à margem dos sistemas jurídicos nacionais. A mais preciosa manifestação da Nova Ordem Jurídica Mundial.

A composição hodierna da new law merchant é tão rica quão complexa e interessante. Fruto da evolução dos tempos, revela-se a partir do processo de sedimentação ou cristalização na vida mercantil. Passamos, ora, a expor os seus mais marcantes elementos ${ }^{206}$.

\section{USOS E COSTUMES DO COMÉRCIO INTERNACIONAL}

Não poderemos deixar de relevar a importância daquilo que designamos como os primeiros passos da lex mercatoria. ${ }^{207}$ No fundo, os elementos constitutivos da sua base ou gênese normativa. Falamos dos usos e costumes do comércio internacional ${ }^{208},{ }^{209},{ }^{210}$.

sim. E as correspondentes referências - nova lex mercatoria como o direito apositivo [um direito sempre novíssimo, um direito vivo] da contratação internacional [com as devidas ressalvas ao seu âmbito de aplicação - bem mais amplo - visto estarmos no domínio da contratação internacional], um direito universal-setorial, eminentemente, espontâneo, criado segundo processos jurígenos específicos, constituído por um conjunto de esquemas normativos - autónomos e quási-autónomos - e paranormativos dotados de eficácia na e para a business community. Em síntese, a regulação apositiva da contratação internacional. Um Direito que vive e revive a par do direito dos Estados e de outras revelações de direito que existem em constante interceção.

204 Para mais desenvolvimento Vide CARDOSO RODRIGUES, Ricardo Alexandre Regulação apositiva da contratação internacional - New law merchant, in passim. E as correspondentes referências.

${ }^{205}$ In ibidem.. In passim. $\mathrm{E}$ as correspondentes referências.

${ }^{206}$ Em termos técnicos fontes. De onde brotam todas as formas de disciplina apositiva mercantil transnacional. Ou, no fundo, critérios jurídicos da nova lei dos mercadores.

${ }^{207}$ Uma parte, muito reduzida, da nova lex mercatoria foi positivada pela via consuetudinária ou pela atividade normativa de alguns centros autónomos. Todavia, consideramos que nem por isso na sua prática mercantil transnacional deixara de ser recorrentemente utilizada, pelo que iremos, também, considera-la no nosso estudo.

${ }^{208}$ Como sabemos existe uma distinção, mais ou menos, precisa da ideia de uso e de costume, entre nós, PIRES DE LIMA, F. A. / ANTUNES VARELA J. M., - Noções fundamentais de direito civil, Vol. I, Coimbra, Coimbra Editora, 4. ${ }^{\text {a }}$ ed., 1957, págs., 109-110; GALVÃO TELLES, - Introdução ao Estudo do Direito, Vol. I, Coimbra, 
Implicam, como é sabido, uma prática reiterada e constante (elemento material), a que se acrescerá a correspondente aceitação, certeza ou convicção (da rotina, prática ou rito) subjetiva e socialmente assumida pelos elementos da comunidade mercantil, cuja dimensão da sua obrigatoriedade varia de acordo com o grau, nível ou dimensão da generalização ou projeção funcional (elemento psicológico: opinio iuris vel necessitatis) ${ }^{211212213}$. Certamente, a fonte mais pura e genuína, mas tam-

Coimbra Editora, 2010, págs. 81 e 96; DIAS MARQUES, J. - Introdução ao Estudo do Direito, 4. ${ }^{\text {a }}$ ed., Lisboa, 1972, pág. 206; CASTRO MENDES, J. - Introdução ao Estudo do Direito, 3. ${ }^{a}$ ed., Lisboa, 2010, pág. 109-111, Vide, também, nota de rodapé n. ${ }^{\circ} 63$; OLIVEIRA ASCENSÃO - O direito. Introdução e teoria geral, Lisboa, Fundação Calouste Gulbenkian, 1978. págs. 218-219, 230-232; BAPTISTA MACHADO, J. - Introdução ao direito e ao discurso legitimador, Coimbra, Almedina, 1990, págs. 158159, 161, Vide in fine. MENEZES CORDEIRO, A. - Costume TUME, Enc. Polis, Vol. I, Lisboa, Verbo, 1983, pág. 1349. Vide, também, SANTOS JUSTO, A. - Introdução ao

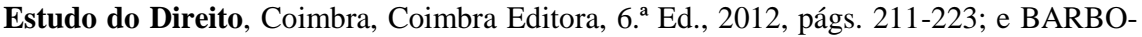
SA RODRIGUES, LUÍS, - Manual de Introdução ao Direito: Interno e Internacional, FORMALPRESS, 2011 págs. 165-169, sobre o costume internacional, in ibidem, págs 163-165.

${ }^{209}$ Diversos autores, defensores da lex mercatoria, qualificam estas regras de direito consuetudinário. Todavia, há autores que consideram que melhor será optar pela expressão usos quando pretendem referir-se à disciplina de origem costumeira, por duas ordens de razão: a primeira porque a destrinça entre uso e costume é difícil devido aos obstáculos tidos pela busca de uma fronteira absoluta; a segunda, pelo facto de a expressão usos, ter sido, recorrentemente utilizada na sua aceção ampla, abarcando, assim, o fenómeno costumeiro. Neste sentido e tendo em consideração, somente, a prática arbitral e o enquadramento real da jurisprudência francesa. Vide. FOUCHARD, Ph. - Les usages, l'arbitre et le juge, in Le droit des relations économiques internationales - Études offertes à Berthold Goldman. Paris, Librairies Techniques, 1983, pág. 68.

${ }^{210}$ Preferimos recorrer à expressão "usos e costumes". Esta englobará as duas expressões, a prática mercantil mais vincada no comércio transnacional. A diferença estará no grau e na amplitude da aceitação dessas práticas, que será tanto maior, no caso do costume, e tanto menor, no caso do mero uso. Atentamos, todavia, as características fundamentais destas práticas.

${ }^{211}$ Quando a lei de um Estado não se adapta às exigências do tráfico mercantil, os comerciantes não aguardam por forma passiva pela disciplina legal adequada, antes recorrem aos usos (lato sensu) extra legen, mais adequados àquelas exigências. O direito mercantil nasce por força do uso, não por força do impulso legislativo. Vide. MARTINEZ CANEELLAS. A. - Temas de Derecho Vivo, Madrid, Civitas, 1978.

${ }^{212}$ Os usos mercantis que se traduzem em práticas reiteradas no mundo dos negócios, que revelam a observância por forma uniforme e generalizada de regras de conduta, ou modus de agir. ANTUNES, J. Engrácia, A. - Direito dos Contratos Comerciais, Coimbra, Almedina, 2009, pág. 58 
bém mais fluida e mutável, acompanhando o pulsar do comércio no espaço transnacional. Não obstante, a sua volatilidade e seu dinamismo que acabam, de certa forma, por obstaculizar a sua captação plena, motivando a energia de fações da doutrina mais céticas em torno da questão da prova efetiva da sua existência, os usos e costumes do comércio internacional têm sido, no decurso dos tempos, objeto de compilação levada a cabo por diversas agências e organizações internacionais ${ }^{214}$, não menosprezando a colaboração fundamental das associações profissionais e corporativas nacionais $^{215}$, procurando superar a sua diversidade, bem como estabelecer correspondências, ligações, critérios equivalentes, estabelecendo um tronco comum, visando um cânone, um padrão ${ }^{216} 217$. Desse trabalho intensivo resulta todo um processo de unificação do corpo normativo, que passará, também, pela supressão de ineficiências lógicas e teleológicas, recriandose, em certos casos, a harmonia jurídico-econômica dos preceitos, potenciando-se, deste modo, a continuidade das relações jurídicas comerciais.

Os INCOTERMS ${ }^{218}$ (ou termos do comércio internacional) ${ }^{219}$ são um bom testemunho do que se vem afirmando. Constituem regras

213 Determinados ordenamentos jurídicos reconhecem a relevância dos "usos de comércio" no âmbito da contratação mercantil, como exemplo: o § 346 do "Handelsgesetzbuch" germânico. Para maiores desenvolvimentos, Vide ANTUNES, J. Engrácia, A. "Consueto Mercatorum" como Fonte do Direito Comercial, in: 146 RDMIEF (2007), 7-22. In nota 52 ANTUNES, J. Engrácia, A. - Direito dos Contratos Comerciais, Coimbra, Almedina, 2009, pág. 58.

${ }^{214}$ Vide DRAETTA, Ugo, - Gli Usi del Commercio Internazionale nella Formazione di Contratti Internazionali, in: DRAETTA, Ugo/ VACCÀ, Cesare (dir.), "Fonti e Tipi del Contratto Internazionale”, Milão, EGEA, 1991, págs. 49-72.

215 Vide FOUCHARD, Ph, - L'arbitrage comercial international, Paris, Dalloz, 1965, pág. 410. P. ex. London Corn Trade Association, Substituída pela Grain and Feed Trade Association Limited of London -MUSTILL, Lord Justice - The New Lex Mercatoria: The First Twenty- Five Years, em Liber Amicorum for the Rt. Hon. Lord Wilberforce, Pc, CMG, OBE, QC, Oxford, Clarendon Press, 1987, pág. 159, n. ${ }^{\circ}$ 37; Outras associações nacionais. KAHN, $\mathrm{Ph}$, - La vente commerciale internationale, Paris, Sirey, 1961, pág. 21; SIEHR, K, - Sachrecht im IPR, transnationales Recht und lex mercatoria, in W. Holl- U. Klinke, Internationales Privatrecht - Internationales Wirtschaftsrecht, Colónia/Berlim/Bona/Mogúncia, Carl Heymanns Verlag, 1985, pág. 314 e n. ${ }^{\circ} 63$.

216 Vide estudo sobre os usos e costumes do comércio internacional. KASSIS, A. Thèorie genèrale des usages de commerce, LGDJ, Paris, 1984, págs. 159-220. Atentese, no entanto, que se trata de um dos autores que nega o carácter substantivo da lex mercatoria.

${ }^{217}$ Constituindo aquilo a que podemos chamar usos codificados.

${ }^{218}$ Foi elaborada e publicada pela CCI em 1936 e sofreu sete revisões: 1953, 1967, 1976, 1980, 1990, 2000 e a versão 2010. 
oficiais da Câmara do Comércio Internacional de Paris (CCI ${ }^{220}$ para a interpretação de termos comerciais usados nos contratos relativos a transações transnacionais ${ }^{221} 222223{ }^{224}$.Um outro grande exemplo é o regime jurídico do crédito documentário ${ }^{225}$ que se encontra, essencialmente, previsto nas Regras e Usos Uniformes sobre Créditos Documentários $(\mathrm{CCI})^{226} 227228229230$. Constituem, hoje, disciplina jurídica uniforme de

${ }^{219}$ Regras internacionais de interpretação uniforme da terminologia contratual comercial.

${ }^{220}$ Fundada em 1919.

${ }^{221}$ Especialmente para analisar das responsabilidades dos operadores envolvidos.

${ }^{222}$ Para TETLEY, no âmbito do Direito privado a avaria geral, o salvamento, afretamento e seguro marítimo, constituem dos princípios mais antigos, elaborados como resposta às dificuldades do comércio marítimo. Terão sido difundidas pelos países de tradição anglosaxónica ou romano-germânica. A necessidade de unificação provocou na Europa Medieval o surgimento da Lex mercatoria transnacional, e como parte dela a Lex marítima. Sobre a história do Direito Marítimo e do "Almirantado". TETLEY, William. - International Maritime and Admiralty Law. Québec, Éditions Yvon Blais, 2002, pág. 4.: pág. 3-30.

223 Vide site International Chamber of Commerce (ICC), disponível em: http://www.iccwbo.org.

${ }^{224}$ Vide site Portugal International Chamber of Commerce (Delegação Nacional Portuguesa da Câmara de Comércio Internacional), disponível em: http://www.iccportugal.com/.

225 Contrato atípico e inominado. Sobre a natureza jurídica Vide. PINA, C. COSTA Conceito, Estrutura e Natureza dos Créditos Documentários, págs. 111 e ss. In: "Estudos Jurídicose Económicos em Homenagem ao Professor Doutor João Lumbrales", págs. 95-117, Coimbra, Coimbra Editora, 2000. Vide também, UREBA, A. Alonso Naturaleza y Régimen der Crédito Documentário, in: AAVV, “Contratos Bancários”, págs 437-490, Madrid, Civitas, 1992.

${ }^{226}$ CCI - Uniform Customs and Practice for Documentary Credits/ /2007 Revision. 2007, p. 66.

227 Adotadas em 1933, revistas em 1951, depois em 1962, mais tarde, em 1975, logo depois em 1983, seguidamente em 1993, em 1 e em 2007 (UCP600) sua última versão. InRevista > Ano 2007 > Ano 67 - Vol. I - Jan. 2007> Doutrina, MENEZES CORDEIRO A. - Créditos Documentários. Disponível em: http://www.oa.pt/Conteudos/Artigo s/detalhe_artigo.aspx $?$ idc $=30777 \&$ idsc $=59032 \& i d a=59051$. Consultado em $:$ 19-02-2015.

228 A respeito das duas últimas versões Vide. BYRNE, J. - The Comparison Between UCP500 and UCP600, Institute of Banking Law and Practice, Montgomery, 2007. DURÁ, R. Marimón - La Nueva Editión de las Reglas de la CCI para los Créditos Documentários, in: 263 RDM, 2007, págs. 7-68.

${ }^{229}$ I - As Regras e Usos Uniformes sobre Crédito Documentário (RUU) constituem direito dispositivo para o qual as empresas remetem a regulação das suas relações contratuais plurilocalizadas, ao abrigo do princípio da liberdade contratual, enquanto expressão da denominada «lex mercatoria». II - A natureza jurídica dos créditos documentários, face à ausência da sua previsão legal, 
vocação universal ${ }^{231} 232$. Existem, ainda, as regras uniformes relativas às cobranças $(\mathrm{CCI})$ e as regras e usos uniformes para as garantias contratuais $(\mathrm{CCI})^{233}$.

Atente-se, que os usos e costumes do comércio internacional cristalizam-se, o mais das vezes, setorialmente:

Esse processo passa pela especialização em diferentes setores do Direito Comercial Transnacional. Assim, e designadamente, no âmbito das construções, a lex constructionis ${ }^{234}$; no âmbito do comércio eletrônico, a lex eletrônica, informática ou numérica; no setor dos derivados do petróleo, gás e carvão, a lex petrólia ${ }^{235}$; no setor bancário, a lex argentarium; no que tange aos assuntos relacionados com o mar, a lex marítima.

no ordenamento jurídico português, só pode ser encontrada, através do regime jurídico definido pelas RUU. Negrito nosso. In Acórdão do Supremo Tribunal de Justiça, $1^{a}$ SECÇÃO, processo n. ${ }^{\circ}$ 406/09.0YFLSB, em 22-09-2009.

${ }^{230}$ Sob a sua égide a CCI reconhece, já, todo um conjunto de documentos desenvolvidos pelos associados, com expressão significativa na prática mercantil internacional. Entre os quais: os Forwarders Certificate of Receipt (FCR); Forwarders Certificate of Transport (FTC); Negotiable Fiata Combined Transport Bill of Lading (FBL). Neste sentido Vide. GOODE, Roy - Commercial Law, Penguin, Middlesex / New York, 1982, págs. 566 e ss, Para mais desenvolvimentos a respeito. PINA, C. Costa - Créditos Documentários As regras e Usos Uniformes da Câmara de Comércio Internacional e a Prática Bancária, Coimbra, Coimbra Editora, 2000.

${ }^{231}$ Neste sentido. EBERTH, Rolf - Zur Rechtnatur der Einheitlichen Richtlinien un Gebräuche für Dokumentenakkreditive, in : "Festschrift für Karl-H. Neumayer", Nomos, Baden-Baden, 1986, págs. 199-216; PINA, C. Costa - Créditos Documentários As regras e Usos Uniformes da CCI e a prática Bancária, Coimbra, Coimbra Editora, 2000 .

${ }^{232}$ No mesmo sentido destacamos a seguinte jurisprudência. Acórdão STJ de 16-07-1970, in: 198 BMJ, 1970, págs. 163 - 172.

${ }^{233}$ Sobre as regras as uniformes relativas às cobranças e as regras uniformes para as garantias contratuais. Vide SACARRERA, Guardiola, E. - La Compraventa Internacional: Importaciones y exportaciones. Barcelona, Bosch, Casa Editorial, S.A., 1994, págs. 2324.

${ }^{234}$ Vide MOLINEAUX, CH. - Moving toward a Construction Lex Mercatoria: A Lex Constructionis, Journal of International Arbitration, 1997, pág. 56.

${ }^{235}$ Vide BERGER, K., P. - The Relationship between the UNIDROIT Principles of International Commercial Contracts and the New Lex Mercatoria, Uniform Law Review, 2000-1, págs. 153-170. 


\section{OS MODELOS JURÍDICOS: CONTRATOS-TIPO E FORMULÁRIOS STANDARD}

Os modelos jurídicos têm, também, especial importância no labor do comércio internacional ${ }^{236}$. Falamos dos contratos-tipo e dos formulários standard $^{237}$, que na prática da contratação transnacional se materializam operando como condições contratuais gerais, correspondendo a parte ou mesmo à totalidade do contrato. Constituem, enquanto fonte, em termos globais, um mecanismo unificador, de fato, do conteúdo da nova lex mercatoria ${ }^{238}$.

Para alguns, representam formas de expressão da prática mercantil $^{239} 240$. Consideramos, todavia, que certos modelos jurídicos são

236 Vide BAPTISTA, Luiz Olavo, - Les Joint ventures dans les relations internationales, Doutoramento, Paris, 1981, in passim.

237 O contrato constitui, de facto e de direito, um elemento fundamental da Lex mercatoria. A sua centralidade tem como motivo o facto de corresponder a um instrumento adequado à configuração do mercado (físico e virtual), bem como, por ir de encontro às exigências jurídicas da globalização, atente-se o caráter apolítico. Vide FERRARESE, M ${ }^{\mathrm{a}}$. R. - La lex mercatoria tra storia e attualità: da diritto dei mercanti a lex per tutti? , Sociologia del Diritto, Milan, 2005, pág. 161. Vide, também, na mesma linha de entendimento. E. LOQUIN ; L.RAVILLON - "La creation d'un espace juridique mondial. La volonte des operateus vecteurs d'un droit mondialise", La Mondialisation du Droit. E. LOQUIN e C. KESSEDJIAN (dirs), Dijon Litec, - CREDIMI, 2000, págs. 91 e ss.

${ }^{238}$ A harmonização tende a desenvolver-se através dos contratos elaborados por associações de operadores internacionais em determinados sectores ou produtos. MARTINEZ CAÑELLAS. A. - La interpretación y la integración de la Convención de Viena sobre la compraventa internacional de mercaderías de 11 de abril de 1980, Granada, Ed. Comares, 2004, pág. 28. Natural será, que esses contratos tendam, de alguma forma, a favorecer os membros da associação que os elaborou.

${ }^{239}$ Ampliando o sentido de "usos do comércio internacional." Os Contratos-tipo, elaborados por organizações socioprofissionais, constituiriam um instrumento uniformizador das condutas dos seus membros, no âmbito do respetivo setor mercantil. Neste sentido, cf. GOLDMAN, B. - Frontières du droit et «lex mercatoria», in Archives de philosophie du droit, n. ${ }^{\circ} 9$ - Le droit subjectif en question, Paris, Sirey, 1964, pág. 180; FOUCHARD, Ph, - L'Etat face aux usages du commerce international, in TCFDIP 1973/1975, Paris, Dalloz, 1977, pág. 74; MARMOL, Ch. Del, - Les clauses contractuelles types, facteur d'unification du droit commercial, in Liber Amicorum Baron Louis Frédéricq, Vol. 1, Gand, Faculteit der Rechtsgeleerdheid te Gent, 1965, pág. 310 ; LOQUIN E. - L'amiable composition en droit comparé et international Contribution à l'étude du non-droit dans l'arbitrage commercial, Paris, Librairies Techniques, 1980, pág. 310. Infere-se do escrito por alguns autores que os contratos elaborados por organizações socioprofissionais identificam-se com os usos escritos, tratase de documentos que consagram e ajustam as práticas adotadas no setor mercantil onde 
fruto das práticas mercantis comumente aceitas entre os operadores do comércio internacional, nos diversos setores mercantis em que os mesmos se situam, como forma de disciplinar, eficientemente, os seus contratos. Não recorrem, por isso, aos critérios jurídicos dos direitos nacionais, aliás, pouco flexíveis, o mais das vezes, obsoletos, desajustados à dinâmica deste comércio.

Atente-se o pragmatismo dos critérios e a natureza observacional do método edificador dos modelos.

As diversas instituições incumbidas de compilar estas práticas, e no intuito de prever todos os eventuais circunstancialismos contratuais, modelam-nas intensivamente a ponto de elencarem pormenores, muito além dos seus carateres constitutivos ${ }^{241}$.

atuam aqueles membros. Vide. LOUSSOUARN, Yvon ; BREDIN, Jean-Denis, - Droit du commerce international. Paris, Sirey,1969, pág. 46; SCHMITTHOFF, C. - The Law of International Trade, Ist Growth, Formulation and Operation, in The Sources of the Law of International Trade (With Special Reference to East-West Trade), Londres, Stevens \& Sons, 1964, pág 16; DAVID, R. - L'arbitrage dans le commerce international, Paris, Económica. 1982, pág. 485. Outros autores incluem os contratos tipo na lex mercatoria, mas não como fonte. Ela seria constituída por usos do comércio e aqueles contratos seriam "custom and usages. "Vide LANDO, O. - The lex mercatoria in International Commercial Arbitration, in International Comparative Law Quarterly ICLQ, 1985, pág. 751. GOLDSTAJN, A. - Usages of trade and other autonomous rules of international trade according to the UN (1980) sales convention. In International sale of goods; Dubrovnik lectures. Sarcevic, P. and P. Volken, eds. New York, Oceana, 1986, pág. 72.

${ }^{240}$ Também no sentido de ampliar o conteúdo da expressão "usos dos comércio internacional. "A utilização generalizada das cláusulas standard para certos tipos contratuais, manifestaria uma atitude comum assumida pelos operadores do comércio transnacional no que concerne à necessidade de adotar soluções diversas daquelas que os direitos nacionais preconizam para os aspetos elencados nessas cláusulas. Aquelas cláusulas constituiriam fontes da lex mercatoria (em muitos casos contêm cláusulas de "força maior" e de hardship para contratos de longa duração). Vide, entre outros autores, GOLDMAN B., La lex mercatoria dans les contrats et l'arbitrage international: realité et perspectives, Clunet Vol. 106 : 475-505, 1979, págs. 487 - 489; KAHN Ph., -'Lex mercatoria' et pratique des contrats internationaux : l'expérience française, in Le contrat économique international - stabilité et évolution, Travaux des VII es Journées d'études juridiques Jean Dabin, Bruxelas/Paris, Bruylant/Pedone, 1975, pág. 185 e ss , KAHN Ph., - Force majeure et contrats internationaux de longue durée, in Jus et Societas - Essays in Tribute to Wolfgang Friedmann, Haia/Boston/Londres, Martinus Nijhoff, 1979. pág. 200; ROBERT, J. - L'arbitrage - droit interne - droit international privé. 5. ${ }^{a}$ edição, Paris , Dalloz, 1983, pág. 286; SCHMITTHOFF, C. The Law, ob. cit. pág. 16; GOLDSTAJN, A.- Usages of Trade, ob. cit. pág. 72; LANDO, O. - The lex mercatoria, ob. cit. pág. 751.

${ }^{241}$ Vide nota . $^{\circ} 16,17,19$ 
Pretende-se, com a sua elaboração, a estandardização dos contratos e a consequente divulgação através de modelos contratuais que correspondem, no fundo, a fórmulas contratuais.

O desiderato último será o de, paulatinamente, obter uma efetiva conversão, nos diversos setores de atividade mercantil, do uso do modelo em costume ${ }^{242}$.

As instituições coletoras, criadoras e promotoras dos modelos são, normalmente, associações ou organizações comerciais internacionais, v. g. a London Corn Trade Association (LCTA), que após fusão com a London Cattle Food Association (LCFA) institui a Grain and Feed Trade Association (GAFTA em 1971) ${ }^{243}$.

A Comissão Econômica para a Europa das Nações Unidas (ECE) ou United Nations Economic Commission for Europe (UNECE), ${ }^{244}$ tem-se dedicado à formulação das condições gerais de venda por setores de atividade, tendo por base as diversas práticas mercantis ${ }^{245} 246247$. Com

${ }^{242}$ Vide SACARRERA, Guardiola, E. - La Compraventa Internacional: Importaciones y exportaciones. Barcelona, Bosch, Casa Editorial, S.A., 1994, pág. 24.

243 Cf. The Bristol Corn \& Feed Trade Association. Disponível em: http://www.bcfta.org.uk/history.php.

Consultado em: 24-02-2015

${ }^{244}$ Conta com 56 Estados Membros.

${ }^{245}$ Entre outros autores, Vide KAHN, Ph.- La vente commerciale international, Sirey, Paris, 1961, págs. 19 e ss.; KAHN, Ph.- L'interprétation des contrats internationaux, in Clunet, 1981, pág. 10; GOLDMAN, B. - Frontières , ob. cit. pág. 181, GOLDMAN, B. - La Lex mercatoria, ob. cit. pág. 478 ; LEVEL, P. - Le contrat dit sans loi, in ICFDIP 1964/1966, Paris, Dalloz, 1967, pág. 212 ; FOUCHARD, Ph. - L'arbitrage commercial international, Paris, Dalloz, 1965, págs. 411 - 412, FOUCHARD, Ph. L'Etat face, $o b$. cit., págs. 74 - 77; LOUSSOUARN, Yvon ; BREDIN, Jean-Denis, Droit du commerce, $o b$. cit. págs. 47 - 48; VRIES H. de, - Le caracteres normatif des pratiques commerciales internationales, in Hommage à Frédéric Eisemann, Paris, CCI, 1978, págs. 120 - 124; EISEMANN, F. -Usages de la vente commerciale internationale - Incoterms : aujourd'hui et demain, Paris, Editions Jupiter, 1980, págs. 43-45; SCHMITHOFF, C. - Das neue Recht des Welthandels, in Rabels Zeitschrift für ausländisches und internationals Privatrecht, 1964, págs. 64 a 68, SCHMITHOFF, C.The Law, ob. cit. págs. 16 - 18; LANDO, O. -The lex mercatoria, ob. cit. págs. $750-$ 751; GOLDSTAJN A., - International conventions and standard contracts as means of escaping from the application of municipal law -1 . The sources of the law of international trade with special reference to East-West Trade., Schmitthoff, C. M. ed., London , Stevens \& Sons, 1964, pág. 116; LOQUIN, E. - L’amiable, ob. cit. pág. 311.

246 Site Institucional. - About Unece. Disponível em: http://www.unece.org/aboutunece.html.

Consultado em: 06-03-2015 
especial relevo: "Maquinaria e outros equipamentos mecânicos e elétricos;" "Bens de Consumo duradouros;" "Madeira"; também, para a venda de cereais e combustíveis sólidos 248249 .

No caso, particular, do contrato de engineering (global), contratos de construção de obra civil e contratos de trabalhos elétricos e mecânicos existe um modelo contratual FIDIC - instituído pela International Federation of Consulting Engineers (FIDIC) - relativo às denominadas civil conditions of red book 250251.

A Instituição de Engenheiros Elétricos procedeu, também, à criação de formulários sobre condições gerais de contratos de exportação, tal como outras associações dos setores siderúrgico (Bruksindustriföreningen), da fundição - Committe of European Foundry Association. Na mesma esteira, as associações do setor das madeiras - Federação Belga do Comércio de Importação de Madeira, Associação Sueca de Exportadores de Madeira, Associação de proprietários de Serralharias Finlandesas, Timber Trade Federation of the United Kingdom - do algodão em rama Centro Algodoeiro Nacional, American Cotton Shippers Association - do papel - Finnish, Noorwegian and Swedish Papermakers Associations entre outros ${ }^{252}$.

No âmbito do mercado financeiro, salientamos as euroemissões, que, por sua vez, constituem um verdadeiro quadro disciplinador de todo um conjunto de operações de especial relevo no espaço euro-

${ }^{247}$ Fundada para promover a cooperação económica entre os Estados Membros. UNITED NATIONS ECONOMIC COMMISSION FOR EUROPE, Disponível em: http://www.UNECE.org/ceci/welcome.html, Consultado em: 24-02-2015.

248 Sobre o fornecimento, montagem, importação e exportação de bens instrumentais; sobre a venda para importação e exportação de bens de consumo duradouros e de outros produtos de natureza industrial.

${ }^{249}$ Vide SACARRERA, Guardiola, E. - La Compraventa Internacional, ob cit ,pág. 24.

${ }^{250}$ De que já existe uma tradução em português promovida pela Associação Portuguesa de Projectistas e Consultores (APPC), membro da Federação Internacional de Engenheiros Consultores (FIDIC), contando com a colaboração da sociedade de advogados Linklaters LLP Lisboa.

251 A este modelo podem, no entanto, ser introduzidos princípios gerais ou que decidam incorporar cláusulas concretas como as de força maior ou hardship. Vide HERNÁNDEZ RODRÍGUEZ, A.- Los Contratos internacionales de construcción “llave en mano", Granada, Comares, 1999 pág. 385

252 Vide SACARRERA, Guardiola, E. - La Compraventa Internacional, ob. cit., págs. 24-25. 
peu $^{253}$, bem como, o master agreement, contrato-quadro e os modelos contratuais em matéria de swaps (troca de posições jurídico-econômicas entre operadores $)^{254}$ criados pela ISDA - International Swaps and Derivates Association $^{255}$.

Finalmente, destacamos, ainda, as soluções uniformes e as regras standard, para os euromercados primário e secundário, criadas pelas International Securities Market Association - ISMA - anterior Association of International Bond - AIBD ${ }^{256}$ - e International Primary Market Association - IPMA, desde Julho de 2005, International Capital Market Association - ICMA ${ }^{257}$.

Outras associações terão divulgado modelos de condições gerais no âmbito das atividades que representam, nomeadamente: Grain and Feed Trade Association (GAFTA), sobre contratos de venda e embarque de cereais ${ }^{258}$; Association of West European Shipbuilders, sobre contratos de construção de navios ${ }^{259}$.

Finalmente, as regras adotadas pelo Comitê Marítimo Internacional, denominadas regras de Iorque - Antuérpia, destinadas a regular alguns aspetos das relações entre o armador, o proprietário da mercadoria,

${ }^{253}$ Vide KAHN, Ph, - Lex mercatoria et euro-obligations, in Law and Înternational Trade - Festschrift fur Clive M. Schmitthoff, Frankfurt a. M., Athenaum Verlag, 1973, págs. 215 e ss. Vide também, Comissão Europeia, - o Livro Verde sobre a viabilidade da introdução de obrigações de estabilidade. Bruxelas, 23-11-2011 COM (2011) 818 final.

254 Vide AIDAN, P. - Droit des marchés financiers. Reflexión sur les sources. La Revue Banque, 2001, pág. 271.

${ }^{255}$ Vide site ISDA: http://www2.isda.org/.

256 Vide site ICMA: http://www.icmagroup.org/. - História da ICMA.InInternational Capital Market Association - ICMA .Disponível em: http://www.icmagroup.org/AboutICMA/Organisation/history.aspx . Consultado em: 21-02-2015.

257 In ibidem..

258 A Grain and Feed Trade Association sobre o comércio internacional de grãos. Vide AIDAN, P. - Droit des marchés financiers. Reflexión sur les sources. La Revue Banque, 2001, pág. 270. Grain and Feed Trade Association sobre comércio internacional de grãos. Sobre as Organizações de autorregulação setorial Vide FERNÁNDEZ ROZAS, J. C. - Ius mercatorum. Autoregulación y unificación del derecho de los negócios transnacionales. Colegios Notariales de España, Madrid, 2003.

${ }^{259}$ Vide SACARRERA, Guardiola, E. - La Compraventa Internacional: Importaciones, ob. cit. pág. 24 
o afretador e as respetivas entidades seguradoras, no caso de avaria grossa

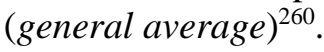

A uniformização contratual internacional aproxima, universaliza e introduz o elemento eficiência ao tráfico comercial transnacional. Por outro lado, o reconhecimento da validade de um determinado tipo contratual, por parte de um grande número de países/entidades, redimensiona, esbate gradativamente os motivos equacionados pela jurisprudência, pondo em evidência, em destaque a invalidade de um contrato que não cumpra os cânones do direito interno ${ }^{261}$, sobretudo, quando questões de ordem pública não são, de todo, colocadas ou postas em discussão.

Sublinhamos, neste e noutros domínios, a fundamentalidade do papel dos técnicos e estudiosos da dogmática e da filosofia contemporâneas. No fundo, a importância crescente do "Homem Jurista" dos tempos atuais, seja na qualidade legislador, de intérprete ou aplicador do direito ao caso concreto. O pensador, o filósofo e o prático, que com os olhos postos no passado e os pés no presente, aponta vias, caminhos e perspetivas para os diversos edifícios normativos e correspondentes dinâmicas. De fato, o direito, em constante diálogo com o mundo, a vida e as pessoas, na sua especial, porque característica, relação de colisão-cooperação com as restantes ciências, vai encontrando a sua identidade, a sua autonomia, mas também recriando o seu papel na (re)definição do quadro de valores dirigido às necessidades de justiça, equidade, certeza, segurança, equilíbrio, harmonia que certa e determinada realidade reclama. Deste modo vai redimensionando os contornos, purificando os seus domínios.

Somos do entendimento de que no plano da contratação internacional - em exponencial crescimento - em quantidade e diversidade deveras dinâmica, fluida, transversal, seguindo os impulsos dos ciclos econômicos e financeiros, pelo que, em muito pouco, verdadeiramente categórica - os caracteres formais do racionalismo jurídico (puro) não estão habilitados a dar eficaz cumprimento a complexas necessidades de

\footnotetext{
${ }^{260}$ Consiste na repartição dos prejuízos, sacrificando-se a carga com o objetivo de salvar a embarcação ou o restante da carga. Faz-se o rateio [divisão proporcional] entre os embarcadores dos prejuízos decorrentes do sacrifício. O sacrifício deverá ser equitativo e o perigo iminente e inevitável. Para além do perigo e da existência do sacrifício é necessário o sucesso da ação (total ou parcial). McDOWELL, Carl; GIBBIS, Helen - Ocean Transportation. Washington, Beard Books, 1999, pág. 333.

${ }^{261}$ Neste sentido Vide MARTINEZ CAÑELLAS. A. - La interpretación y la integración de la Convención de Viena sobre la compraventa internacional de mercaderías de 11 de abril de 1980, Granada, Comares, 2004, pág. 32
} 
eficiência econômica, acabando, nestes domínios, por se ver esbatido o alcance lógico e teleológico, bem como, em muitos casos, o cumprimento efetivo dos valores e princípios jurídicos (formais).

Um contrato comercial internacional cumpre um papel de natureza econômica e/ou financeira direto, com relação aos implicados, e indireto por efeito da participação na vida econômica de diferentes Estados, com diferentes graus de afetação social, econômica, financeira e até cultural.

O valor jurídico de dada operação, associado ao valor econômico dos interesses em jogo e consequente impacto nas diferentes esferas (implicadas e atingidas) de interesse permitir-nos-á balizar a mais-valia da introdução de critérios de racionalidade de cariz econômico.

A tecnicidade, por um lado, a natureza, dinâmica e fluidez, por outro lado, características da realidade em discussão, exigem respostas com recurso à racionalidade jurídica e econômica ${ }^{262}$. Pugnamos pela articulação destas duas construções lógicas na implementação de uma disciplina da contratação internacional, que não descurando os mais altos valores e princípios estruturantes do direito, em particular, do direito da contratação internacional, promova a eficiência negocial fitando o que na ciência econômica se denomina de primeiro ótimo.

O singelo pressuposto econômico de que as necessidades são, de fato, ilimitadas e os recursos são, na verdade, escassos, em alinhamento como o fator impacto - econômico, financeiro e social - das decisões de natureza negocial, exigem, pelo menos, uma reflexão para o exposto.

A articulação da racionalidade econômica com a racionalidade jurídica promoverá o aumento e continuidade das operações negociais pela introdução do fator eficiência; simultaneamente, potenciará o desenvolvimento econômico e financeiro eticamente sustentável, na promoção duma sociedade global mais justa e equilibrada.

No fundo, ambas as racionalidades se entrecruzam e cooperam na construção da solução mais adequada para o caso concreto.

262 Para mais desenvolvimentos sobre a racionalidade económica Vide PAZ ARES, C. Principio de eficiência y derecho privado, Estudios en homenaje a M. Broseta Pont. Tirant lo Blanch, Valencia, 1995. Vol III, págs. 2843-2900. 


\section{OS CONTRATOS AUTORREGULADORES OU AUTO NORMATIVOS (SELF REGULATORY CONTRACTS)}

Nascidos sob a égide do princípio da autonomia da vontade reconhecido, por todos os ordenamentos jurídicos - (corolário fundamental do valor / princípio dignidade da pessoa humana) concretizada na liberdade contratual, na decorrência da liberdade de disciplinar ${ }^{263}$, os contratos autorreguladores ou auto normativos (sef regulayory contracts) revelam-se instrumentos negociais autônomos e independentes, porque, autodeterminados, autodisciplinados, intrinsecamente autossuficientes, intencionalmente blindados ao influxo regimentador dos Estados, porque estrategicamente garantidos, o mais das vezes, pela combinação de um compromisso arbitral - de equidade - ou recurso à composição amigável.

Configuram, por efeito do exposto, reais paradigmas das potencialidades negativas ou paralegalistas de um dado edifício normativo com relação à disciplina jurídica nacional, potencialmente, aplicável ${ }^{264}$.

Numa acepção mais ampla, poderão ser denominados "contratos sem lei" ${ }^{265}$, sempre que as esferas de interesse, deliberadamente, decidam subtrair o contrato à regimentação Estadual, e optem diretamente pela lex mercatoria nas suas diversas manifestações ${ }^{266}$.

Não obstante, as virtualidades positivas da celebração de um contrato desta natureza, mormente, o elevado grau de segurança e previsibilidade, pela minúcia que subjaz à sua edição veem-se dramatizados os custos de transação associados para as esferas de interesse implicadas.

\footnotetext{
263 "Autonomia é o poder de dar-se um ordenamento. Neste sentido substancial, a autonomia privada significa que a ordem jurídica global admite que os particulares participem da construção da sua própria ordem jurídica, nos quadros embora da ordem jurídica global" in ASCENSÃO, JOSÉ DE OLIVEIRA, - Teoria Geral do Direito Civil. Volume III. Acções e Factos Jurídicos, Lisboa, s. ed., 1991/1992., pág. 39. Para mais desenvolvimentos, In ibidem, págs. 40- 42.

${ }^{264}$ Vide. MARTINEZ CAÑELLAS. A. - La interpretación y la integración de la Convención de Viena sobre la compraventa internacional de mercaderías de 11 de abril de 1980, Granada, Comares, 2004, pág. 31

${ }^{265}$ Entenda-se lei (sentido amplo) e positiva.

${ }^{266}$ A propósito do ius ingeniorum. Vide MAYER, P. - Droit international privé et droit international public sous l'angle de la notion de compétence, $R$. critique, págs. 1-29, 349-388, 537-583, pág. 460.
} 


\section{OS CONTRATOS ATÍPICOS (SOBRETUDO OS TIPOS SOCIAIS)}

O comércio transnacional é muito rico no que toca à diversidade de figuras contratuais comerciais. Que ascendem a tipos contratuais transnacionais quando reveladores de uma fisionomia jurídica própria ou individualidade técnica e formal no que tange aos caracteres fundamentais do negócio jurídico em causa (1) e cumpram uma função de natureza econômica (2) ${ }^{267}$, bem como de cariz social, dirigida à comunidade de mercadores, para a qual foi desenhada.

Vários são os tipos contratuais existentes no espaço transnacional: desde típicos (como a compra e venda ${ }^{268}$ e a agência [no plano dos direitos nacionais]), verdadeiramente atípicos e inominados, reconduzíveis a tipos sociais ou não ${ }^{269}$.

Nos últimos tempos, os contratos comerciais transnacionais designados como tipos sociais têm-se revelado uma elevada expressão no tráfico comercial transnacional, atendendo tanto à envergadura dos investimentos, como ao volume de contratos comerciais realizados. Referimonos, a título de exemplo, ao contrato de global engineering em todas as suas dimensões 270 271. Trata-se de um contrato atípico face aos ordenamentos jurídicos nacionais, sem regulamentação jurídica específica e, por decorrência, inominado, sem "nomem iuris" 272.

\footnotetext{
${ }^{267}$ Vide PAIS DE VASCONCELOS, Pedro, - Contratos Atípicos. Coimbra, 1995, pág. 61.

268 Tipicidade interna nos principais sistemas jurídicos estaduais e tipicidade internacional (ex.: Convenção de Viena de 1980 e Roma I)

${ }^{269}$ Segundo Lima Pinheiro, contrato de joint venture escapa a qualquer forma de tipificação social. LIMA PINHEIRO, ob. cit. pág. 37.

${ }^{270}$ Para mais desenvolvimemtos. Vide CARDOSO RODRIGUES, Ricardo Alexandre - O Contrato de Engineering: Algumas Reflexões (The Engineering Contract: Some Reflection), Setembro de 2014, Disponível na SSRN: http://ssrn.com/abstract=2545393. $\mathrm{E}$ as referências.

${ }^{271}$ Um contrato muito conhecido no comércio internacional. CALVO CARAVACA, A.L. - CARRASCOSA GONZÁLEZ, J. E OUTROS - Derecho internacional privado, Vol. II, Granada, Comares, 2000, pág. 394

${ }^{272}$ Vide MENEZES CORDEIRO. - Direito das Obrigações, A. A. F. D. L., Lisboa, 1986 (reimpressão) e Pessoa Jorge - Direito das Obrigações: A.A.F.D.L., Lisboa, 1974, Págs. 174 e ss.; em sentido contrário, no entanto, cfr. Inocêncio Galvão Telles, Manual dos Contratos em Geral. 3. a edição, Petrony, Lisboa, 1965, pág. 382, e Direito das obrigações. 6. ${ }^{a}$ Edição, Almedina, 1989, pág. 68.
} 
Outro exemplo de contrato com expressão no tráfico negocial, mas, sem um regime específico, pelo menos, no nosso ordenamento jurídico, é o de concessão comercial, ao qual se aplica, em tudo o que for de acordo como sua natureza jurídica, o disposto para o contrato de agência (entre nós, o decreto-lei n..$^{\circ}$ 176/86, de 3 de Julho, com as alterações introduzida pelo Decreto-lei n. ${ }^{\circ}$ 118/93, de 13 de Abril, pela necessidade de transpor, para o ordenamento jurídico nacional, a Diretiva do Conselho da Comunidade Europeia n. ${ }^{\circ}$ 86/653/CEE, de 18 de Dezembro de 1986) ${ }^{273}$.

A liberdade negocial de que dispõem os operadores do mercado (físico e virtual) transnacional (empresas multinacionais e transnacionais) possibilita-lhes usar a sua criatividade e fazerem surgir novos instrumentos contratuais - através da prática reiterada de certa atividade no seio do comércio transnacional (usos e costumes contratuais) - mais adequados à dinâmica negocial do setor de atividade respetivo. A par dos operadores de mercado e dos consultores de associações internacionais das diversas atividades empresariais desenvolvidas e constitutivas do mercado internacional $^{274}$.

Este ato criativo tem muito de operativo, visto partir, a maior parte das vezes, da prática da atividade para a disciplina regulativa, constante do clausulado.

\section{A JURISPRUDÊNCIA, EM PARTICULAR A ARBITRAL}

A jurisprudência, em particular a arbitral ${ }^{275}$ tornou-se, desde cedo, um campo fértil para o desenvolvimento da lex mercatoria.

\footnotetext{
273 Também designados como "tipos do tráfico negocial". Vide PAIS DE VASCONCELOS, ob. cit. pág. . 59 e ss. e LIMA PINHEIRO - Contratos de Empreendimento Comum (Join Venture) em Direito Internacional Privado, Lisboa, Almedina., 1998, págs. 72 e ss, e as referências.

274 "En la escena actual del derecho, nada es más uniforme internacionalmente que el contrato atípico". Vide GALGANO, F., - La globalizzazione nello specchio del diritto, Bologna, Il Moulino. 2005. Tradução espanhola por Roitman, H. y De La Colina, $\mathbf{M}^{\mathbf{a}}-$ La globalización en el espejo del Derecho, Santa Fe, Rubinzal-Culzoni. 2005, pág. 106. E ainda, "Con la recepción jurisprudencial de los contratos atípicos internacionalmente uniformes se logra paulatinamente la uniformidade internacional del Derecho privado", pág. 109.

${ }^{275}$ É intrinsecamente contratual, visto carecer de um acordo escrito entre outros requisitos processuais constantes na Convenção de Nova York de 1958 e na Lei Modelo da CNU-
} 
Estudos têm revelado, principalmente nos últimos anos, um significativo aumento do número de soluções - no todo ou em parte - autônomas desenvolvidas pela jurisprudência arbitral, que, a nosso ver, tanto deve ao contínuo labor dos juristas, técnicos/ especialistas, associações, mas, sobretudo, ao talento criativo, ao esforço de modelação normativa, empenho e resiliência dos juízes árbitros ${ }^{276} 277$.

A vida mercantil hodierna conta já com uma parte substancial dos operadores do comércio transnacional (empresas e corporações, ressalvando, talvez, as grandes financeiras internacionais ${ }^{278}$ ) a recorrer à arbitragem do comércio transnacional para dirimir todos os litígios emergentes de contratos comerciais transnacionais, estipulando no próprio instrumento contratual uma cláusula de electio iuris.

$\mathrm{Na}$ verdade, o recurso à arbitragem emerge da latente necessidade de criar mecanismos contratuais habilitados a responder eficientemente às necessidades e às oscilações, fundamentalmente, econômicas dos mercados internacionais.

A arbitragem enquanto instrumento ao serviço da eficiência e, consequente, continuidade das relações comerciais transnacionais destaca

DMI (Comissão das Nações Unidas para o direito mercantil internacional) sobre a arbitragem comercial internacional.

${ }^{276}$ Salientamos, entre tantos, o importante contributo do Prof. Dr. Klaus Peter Berger que no seu Formalisierte oder "schleichende" Kodifizierung des transnationalen Wirtschaftsrecht, Berlim e Nova Iorque, 1996, págs 217 e ss., apresenta uma lista de mais de sessenta regras, princípios e institutos constitutivos da lex mercatoria . Três anos depois, na sua obra, The Creeping Codification of the Lex Mercatoria, A Haia, Londres e Boston, 1999, apresentara nova compilação e fomentara uma base de dados sobre a lex mercatoria (constituída, fundamentalmente, por documentos doutrinários e jurisprudência arbitral) - a Central's Transnational Law Digest \& Bibliography, Disponível em: http://tldb.unikoeln.de/TLDB.html.

${ }^{277}$ Um outro contributo relevante, baseado na jurisprudência arbitral, destaca uma quantidade expressiva de soluções autónomas. CRAIG; PARK; PAULSSON - International Chamber of Commerce arbitration, Oceana Publications, 2000, págs. 642 e ss. Vide também. STEIN Ursula - Lex Mercatoria. Realität und Theorie, Francoforte-sobre-oMeno, 1995 págs 156 e ss; LANDO - Lex mercatoria 1985-1996, in Festskrift til Stig Strömholm, V. II, 567-584, Uppsala, 1997, pág. 576.

${ }^{278}$ Vide MORÁN GARCÍA, M. E. - Derecho de los mercados financieros internacionales, Ed. Tirant lo Blanch,Valencia, 2002, pág. 307. 
diversas vantagens, com as quais a judicatura Estadual não poderá competir por diversas ordens de razão, assim ${ }^{279}$ :

a celeridade (cum grano salis) - pela desburocratização e desformalização processuais. No que tange ao limite temporal, a atual LAV, impõe, salvo convenção das partes em contrário, 12 meses, a contar da aceitação do último árbitro, como limite máximo para a existência de laudo arbitral (art. $43 .^{\circ}$ n..$^{\circ} 1$ );

a flexibilidade - as partes podem escolher: a instituição arbitral, os árbitros, o iter arbitral, o idioma, a lei disciplinadora da arbitragem e do mérito da causa;

a confidencialidade - o procedimento arbitral é sigiloso e a decisão arbitral não é publicada, apenas não será assim se as esferas de interesse consentirem, ou se faltarem ao cumprimento (a publicitação é promovida pela respetiva Organização Empresarial e/ou, também, onde opere o centro arbitral);

a especialização dos árbitros - são pessoas com habilitações em determinadas matérias. O juiz árbitro é o prático, o técnico, o jurista (...), apto a decidir questões que convocam múltiplos conhecimentos, seja de natureza tecnológica, científica, econômica ou técnico-jurídica ${ }^{280}$, potenciando soluções equitativas, previsíveis, adequadas à tecnicidade do assunto;

a neutralidade ${ }^{281}$ - a arbitragem transnacionaliza o litígio, afastando a possibilidade de um determinado Estado, através dos seus tribunais judiciais, favorecer os seus próprios interesses;

a política de apoio institucional ao investimento externo - a arbitragem enquanto forma alternativa de dirimir litígios ${ }^{282}$ ocupar-se-á

279 LIMA PINHEIRO - Direito Comercial Internacional, Coimbra, Almedina, 2005, págs. 345-346; VICENTE, Dário Moura - Portugal e a Arbitragem Internacional, Janus, 2004; LUIZELLA Giardino B. Branco: http://www.cbsg.com.br/pdf_publicacoes/arbitragem_nos_contratos_internacionais.pdf ${ }^{280}$ FERRER CORREIA - "Da arbitragem comercial internacional", in Temas de Direito Comercial. Arbitragem Comercial Internacional. Reconhecimento de Sentenças Estrangeiras. Conflitos de Leis, Coimbra, 1989, págs. 173 e ss.

${ }^{281}$ Que é discutível, no entanto, se o árbitro for parcial no que concerne a determinadas matérias, ou mesmo se agir como representante de parte, violando as suas normas deontológicas. VICENTE, Dário Moura, - Da Arbitragem Comercial Internacional: Direito Aplicável ao mérito da causa, Coimbra Editora, 1990, pág. 19.

${ }^{282} \mathrm{O}$ custo associado à arbitragem poderá ser, todavia, um obstáculo ou desvantagem. In ibidem. Vide a esse propósito, por exemplo, as preocupações demonstradas pela London 
das relações materiais controvertidas de natureza econômica, comercial e industrial, nascidas desses investimentos, descongestionando, dessa forma, os tribunais judiciais.

Atente-se que os árbitros transnacionais que estejam autorizados a julgar segundo a equidade [e a composição amigável] têm a faculdade de basear a sua decisão, tendo por base de sustentação a nova lex mercatoria, no entanto, deverão respeitar os limites mínimos do sentido de justiça $\mathrm{a}^{283}$.

A equidade traduz a justiça material (não normativa) do caso concreto $^{284}$. Que, tendencialmente, implica uma decisão que estabelece uma diferenciação das posições das esferas de interesse num binômio vencedor e vencido. Diferentemente do que ocorre com a composição amigável, pressupõe um certo "equilíbrio dos interesses em jogo", (art. 35. ${ }^{\circ}$ da Lei n. ${ }^{\circ}$ 31/86, de 29 de Agosto / art. 39. n. 3 da Lei n. ${ }^{\circ}$ 63/2011de 14 de Dezembro) ${ }^{285}$ aliás, como acontece, por exemplo, no contrato de transação, no qual existem "recíprocas concessões" (art. 1248. ${ }^{\circ}$, n. $^{\circ} 1$ do $\mathrm{CC})$.

Court of International Arbitration (LCIA). "In order to ensure cost-effective services, the LCIA's administrative charges, and the fees charged by the tribunals it appoints, are not based on sums in issue. A registration fee is payable with the Request for Arbitration and, thereafter, hourly rates are applied by the arbitrators and by the LCIA." In site Institucional - About the LCIA. Disponível em: http://www.lcia.org/LCIA/Introduction.aspx. Consultado em: 05-03-2012.

${ }^{283}$ Constituiriam uma vontade tácita das partes no sentido de a verem aplicada. GOLDMAN, B. - La lex mercatoria, ob. cit. págs. 480-481. A propósito dos Princípios UNIDROIT e LANDO, Lima Pinheiro considera que os árbitros poderão aplica-los - quando as partes entendam por bem que o seu litígio seja solucionado segundo os seus critérios desde que o resultado da sua decisão não seja francamente injusto. LIMA PINHEIRO Direito Comercial Internacional, ob. cit. pág.. 195. Em opinião diferente. Lando, entre outros, entende que "[t]he lex mercatoria obliges the arbitrator to base his decision on the law Merchant even when equity might lead him to another result." LANDO, O. - Lex mercatoria, ob. cit. págs. 754-755.

${ }^{284}$ Neste sentido Vide OLIVEIRA ASCENÇÃO J., O Direito - Introdução e Teoria Geral - Uma Perspetiva Luso- Brasileira, 9. a edição revista, Coimbra, Almedina, 1995, pág. 223; MENEZES CORDEIRO, - A decisão segundo a equidade, O Direito, Ano 122. ${ }^{\circ}, 1990-$ II, págs. 261-280.

285 No mesmo sentido a Lei Modelo da UNCITRAL:

"O tribunal arbitral decidirá ex aequo et bono [equivalente à equidade] ou na qualidade de amiable compositeur apenas quando as partes o expressamente autorizarem" In Art. 28 n. ${ }^{\circ}$ 3 da Lei Modelo da UNCITRAL sobre Arbitragem Comercial Internacional 
Seguindo a terminologia adotada por Boaventura Sousa Santos, na equidade haveria como que uma solução por "adjudicação", cujo resultado é de soma zero, contrariamente ao que carateriza a composição amigável, que apresenta uma solução com natureza de compromisso ou de "mediação" 286287. Não obstante esta distinção, entendemos por bem, nesta sede, considerar ambas equivalentes, visto que as concretas finalidades da composição do litígio devem ser casuisticamente aferidas. Apenas em sede arbitral o intérprete/julgador desvendará qual a justiça reclamada no caso em apreciação. No entanto, no nosso entender, a equidade em sentido amplo oferece uma maior maleabilidade concetual e um caráter, substancialmente, mais jurígeno. A equidade porque direcionada à justiça do caso concreto pode muito bem apelar a uma justiça stricto sensu ou a uma justiça dirigida à composição dos interesses das partes ${ }^{288}$.

Relativamente à aplicação do complexo normativo por forma autônoma, entendemos ser, de todo, uma consequência da conjuntura evolutiva econômica e financeira e do caráter obsoleto, rígido, ultrapassado, dos direitos nacionais face às problemáticas inerentes às constantes transmutações globais. Entendemos que a nova lex mercatoria para além de um valioso instrumento ao serviço da integração do negócio jurídico, constitui um instrumento de regulação mais adequado às exigência da contratação internacional, visando suprir as incertezas a que conduz o método conflitual e a ineficácia dos direitos Estaduais ${ }^{289}$. O juiz árbitro apresenta uma forte linha de interseção relacional com a nova lex merca-

\footnotetext{
${ }^{286}$ SOUSA SANTOS, B., O discurso e o poder - Ensaio sobre a sociologia da retórica jurídica, in Estudos em Homenagem ao Prof. Doutor J. J. Teixeira Ribeiro, II - IURIDICA, Coimbra, Faculdade de Direito, 1979, págs. 245 e ss.

${ }^{287}$ Acerca da mediação Vide FERREIRA DE ALMEIDA, C. - Meios jurídicos de resolução de conflitos económicos, Boletim da Faculdade de Direito de Bissau, n. ${ }^{2} 2$, Setembro de 1993, págs. 179 e ss

${ }^{288}$ Clarificando, na contratação internacional existe uma certa autonomia dogmática nocional relativa aos preceitos supra mencionados. Esse sentido também sofrera as suas alterações, antes constituíam formas de liberar o tribunal arbitral de decidir segundo as regras de direito objetivo passando a constituir mecanismos que dispensa esse mesmo tribunal da aplicação de direito estadual. Vide DAVID, R. - Arbitrage et Droit compare, in RIDC, 1959, pág. 15; KAHN, Ph. - La vente comercial , págs. 39 e ss ; FOUCHARD, Ph.l'Arbitrage, ob. cit., págs. 404 a 406; LEVEL, P. - Le contrat, ob. cit., pág. 230, e LOUSSOUARN, Yvon; BREDIN, Jean-Denis - Droit du commerce, ob. cit. págs. 44 a 45.

${ }^{289}$ No mesmo sentido, GOLDMAN, B. - La lex mercatoria, ob. cit. págs. 484-485 e 492; LEW, J.D.M. - Applicable Law, pág. 437.
} 
toria; relembre-se que o árbitro não tem uma verdadeira lex fori e apresenta-se como o guardião dos interesses do comércio transnacional.

A propósito da via conflitual consideramos premente a transnacionalização das respetivas normas de conflitos no sentido de permitir aos operadores do comércio aplicar a nova lex mercatoria pela via conflitual, sempre que o conteúdo da lei restrinja à determinação de um direito Estadual - visto quando alude às expressões isoladas "direito" e "lei" não

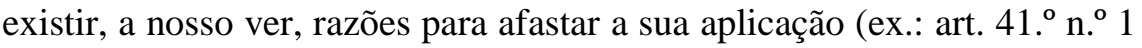
e 2 do Código Civil Português) - permitindo uma certa consolidação das diversas jurisprudências Estaduais e maior consonância de critérios jurídicos.

Finalmente, e com especial relevo, tocamos o húmus da efetividade da decisão arbitral ${ }^{290}$, a sua intangibilidade, efetiva decorrência da sua irrecorribilidade, aspeto revelado de uma certa autonomia institucional das instâncias arbitrais e segurança jurídica pela estabilização dos respetivos laudos arbitrais ${ }^{291} 292$.

Para diversos autores, as decisões arbitrais constituem um importante instrumento de revelação da lex mercatoria ${ }^{293}$. Diríamos de revelação, de (re)validação e novação.

\footnotetext{
${ }^{290}$ Segundo a Lei Modelo da UNCITRAL sobre Arbitragem Comercial Internacional no art. 35 n. ${ }^{\circ} 1$ :

"A sentença arbitral, independentemente do país em que tenha sido proferida, será reconhecida como tendo força obrigatória e, mediante solicitação por escrito dirigida ao tribunal competente, será executada (...)"

${ }^{291}$ Nos termos do n. ${ }^{\circ} 1$ do art. 34 da Lei Modelo da UNCITRAL sobre Arbitragem Comercial Internacional:
}

"O recurso de uma sentença arbitral interposto num tribunal só pode revestir a forma de um pedido de anulação, nos termos dos parágrafos $2 .^{\circ}$ e $3 .^{\circ}$ do presente artigo." O Conteúdo destes parágrafos apresentam requisitos muito apertados.

292 Atente-se que:

"A sentença que se pronuncie sobre o fundo da causa ou que, sem conhecer deste, ponha termo ao processo arbitral, só é susceptível de recurso para o tribunal estadual competente no caso de as partes terem expressamente previsto tal possibilidade na convenção de arbitragem e desde que a causa não haja sido decidida segundo a equidade ou mediante composição amigável. Art. 39 n. ${ }^{\circ} 4$ da atual LAV.

293 Assim KAHN, Ph. - La vente, ob cit. pág. 41. Num estudo mais recente o autor, a propósito do papel dos laudos arbitrais na construção da lex mercatoria, afirma que "(1)e droit international économique reste avant tout un droit contractuel en tant que construction cohérente“. In - Lex mercatoria' et pratique ", pág. 209; FOUCHARD, Ph., L'arbitrage, ob. cit., pág. 446 e ss.; LOUSSOUARN, Yvon; BREDIN, Jean-Denis Droit du commerce, $o b$. cit. págs. 44 - 45; GOLDMAN, B. - La Lex mercatoria, $o b$. 
Para GOLDMAN, no que respeita à disciplina material de determinadas questões jurídicas, seria possível extrair do conteúdo dos laudos arbitrais soluções jurídicas idênticas entre si ${ }^{294} 295296$.

Aquele autor entende que caberia à jurisprudência arbitral um importantíssimo papel no processo de descoberta, revelação, florescimento, desenvolvimento da lex mercatoria. Em particular, no que tange aos princípios - segundo as suas palavras, os princípios gerais de direito rela-

cit. págs. 491 - 497; LANDO, O. - The Lex Mercatoria, ob. cit. págs. 751 -755; DERAINS, Y. - Les normes d'application immédiate dans la jurisprudence arbitrale, in Le droit des relations économiques internationales - Études offertes à Berthold Goldman, Paris, Librairies Techniques, 1983, págs. 29-30. Em sentido contrário, atendendo à falta de coesão e de previsibilidade. Vide VERDERA Y TUELLS, E. - El 'Pierce the Veil, arbitral de Yves Derains. in RCEA, 1985, pág. 46; GODDARD, J. A., - El Jus Gentium, pág. 437; Em sentido semelhante, DAVID, R. - Le droit du commerce international : une nouvelle tâche pour les législateurs nationaux ou une nouvelle « lex mercatoria »?, in New Directions in International Trade Law, vol. I (reports), Nova Iorque, Oceana Publications, 1977, págs. 16-17. Para este autor a criação da lex mercatoria pela via arbitral seria possível, apenas, no seio de certos setores do mercado transnacional (num estudo mais recente depreende-se que exclua a hipótese dessa criação pela via arbitral) DAVID, R.- L'arbitrage, ob. cit. pág. 485.

${ }^{294}$ Vide GOLDMAN - La lex mercatoria, ob. cit. págs. 493-497.

${ }^{295} \mathrm{O}$ mesmo se passa com os critérios escolhidos segundo a via conflitual ou indireta. A prática arbitral nem sempre afasta a via conflitual na regimentação das relações materiais controvertidas. No entanto, optam por critérios distintos do dos ordenamentos jurídicos dos Estados. Nesta linha de raciocínio, alguns autores, incluem, ainda que a título excecional, aos elementos da nova lex mercatoria, o Direito internacional privado da lex mercatoria, constituído pelos critérios, originais, adotados pelos árbitros para a determinação do direito aplicável ao fundo da causa. Vide GOLDMAN, B. - La lex mercatoria, ob. cit. págs. 491-492; Vide LALIVE, P. - Les règles de conflit de lois appliquées au fond du litige par l'arbitre international siégeant en Suisse, in L'arbitrage international privé et la Suisse, Colloque des 2 et 3 avril 1976, Genebra, Georg- Librairie de l'Université, 1977, págs. 90 e ss. Fazendo referência à 'Lex mercatoria' of conflitual rules”, num prisma futurista. Vide MEHREN, A.T. Von, - To What Extent is International Commercial Arbitration Autonomous?, in Le droit des relations économiques internationales - Études offertes à Berthold Goldman, Paris, Librairies Techniques, 1983, pág. 227. Consideramos que a nova lex mercatoria é de natureza material, e poderá eventualmente socorrer-se de um Direito que lhe é paralelo no sentido de complementar a sua disciplina, nomeadamente, em aspetos vitais para o contrato. Nesta linha de pensamento, entendemos estarem compreendidos na nova lex mercatoria todos aqueles critérios jurídicos conflituais originais, essencialmente, fundados em princípios do comércio transnacional, que através do seu modus operandi visem a completude regulativa de um contrato comercial transnacional. Todavia este método teria sempre carácter subsidiário. Negrito nosso.

${ }^{296}$ Vide notas 77 e 78. 
tivos às relações comerciais internacionais e os princípios comuns aos vários sistemas jurídicos nacionais - e respetiva concretização ${ }^{297}$

Da análise da jurisprudência arbitral levantaram-se imensas discussões acerca da aplicabilidade, ao contrato transnacional, da nova lex mercatori ${ }^{298}$. No que tange à sua aplicação efetiva, esta poderá operar autonomamente, por decorrência da escolha de lei $^{299}$ e por forma heterô-

297 Aplicação do Principio da Boa-fé - CCI, n. ${ }^{\circ}$ 2443, 1976; o princípio Pacta sunt servanda-CCI, n. ${ }^{\circ}$ 2404, 1975, n. ${ }^{\circ}$ 2438, 1975. Sobre a jurisprudência que confirma a existência de usos próprios do comércio internacional. Vide MIMOSO, Maria João, - A justiça arbitral na composição dos litígios do comércio internacional. Tese de Mestrado [Texto policopiado], Lisboa: 1994, pág. 139, nota n. ${ }^{\circ} 127$.

${ }^{298} \mathrm{Na}$ verdade ainda predomina a tese de que todo o contrato está, intrinsecamente, conectado a uma ordem jurídica específica, razão pela qual deverá aplicar-se o direito do Estado eleito pelas esferas de interesse. Facto que, em virtude da desmaterialização de diversas realidades fruto da evolução tecnológica e científica, é desprovida de qualquer sentido, atente-se, por exemplo a aquisição de software construídos numa plataforma online e em rede e um serviço de distribuição online (planetário) e em rede para os mesmos produtos. Não obstante, a jurisprudência francesa, no caso Valenciana de Cementos, através da sentença da Cour d'appel de Paris datada a 13 de Julho de 1989, confirmada pela Cour de Cassation em 1991, entender que nos casos em que as partes não designam o direito aplicável ao contrato e os árbitros decidam aplicar a lex mercatoria (nas suas expressões) o juiz Estadual não poderá operar uma revisão da escolha do árbitro quando a decide aplicar. Vide caso anterior Fougerolle y Norsolor. Também na jurisprudência italiana. Vide GALGANO, F. - La globalización en el espejo del Derecho, Rubinzal: Buenos Aires, 2005, págs. 69-70.

299 - A arbitragem comercial internacional representa uma via alternativa e resolução de litígios que, por isso, exclui que essa mesma resolução possa ter lugar na jurisdição estadual comum em que se integram os tribunais judiciais; - Se validamente convencionado o recurso à arbitragem, a determinação do direito aplicável à resolução do litígio "rege-se principalmente por regras e princípios próprios do Direito da Arbitragem Comercial Internacional", sendo permitido que as partes remetam para um Direito estadual, para o Direito Internacional Público, para a lex mercatoria, para "princípios gerais" ou para a equidade; In Acórdão do Supremo Tribunal de Justiça, processo n. ${ }^{\circ}$ 05A2507, em 15-03-2005. A seguinte jurisprudência vai mais longe. I- Quando referida, a interesses do comércio internacional, a arbitragem designa-se por arbitragem internacional, podendo as partes escolher o direito a aplicar pelos árbitros, sendo que, na falta de escolha, o tribunal aplica o direito mais apropriado ao litígio. II- Se validamente convencionado o recurso à arbitragem, a determinação do direito aplicável à resolução do litígio "rege-se principalmente por regras e princípios próprios do Direito da Arbitragem Comercial Internacional", sendo permitido que as partes remetam para um Direito Estadual, para o Direito Internacional Público, para a lex mercatoria, para "princípios gerais" ou para a equidade. III- Não havendo designação expressa, "não há, em princípio, razão para as partes suporem que os árbitros decidirão o fundo da causa segundo o direito em vigor no lugar da arbitragem". Acórdão do Supremo Tribunal de Justiça, processo n. ${ }^{\circ}$ 0636141, 11-01-2007. 
noma, quando nasce da decisão do árbitro em detrimento da vontade das esferas de interesses ${ }^{300}$.

O recurso à arbitragem, como forma alternativa de dirimir litígios, é uma das manifestações que melhor exprime a independência do comércio transnacional. O conteúdo das decisões arbitrais constitui o melhor repositório para justificar a lex mercatoria. Por outro lado, a arbitragem é um instrumento capaz de justificar a importância da instituição de uma Lex mercatoria, enfatizando o gradual afastamento das leis nacionais e das jurisdições estaduais ${ }^{301}$.

Estima-se que em cerca de $90 \%$ dos contratos comerciais internacionais exista cláusula arbitral ${ }^{302}$. Todos os contratos internacionais de global engineering apresentam-na no seu clausulado 303304.

Como sabemos, as partes que não a tenham pré-estipulado poderão sempre, sob compromisso arbitral cometer o seu litígio atual, emergente de uma operação do comércio internacional, à arbitragem transnacional.

É, sem dúvida, no direito marítimo que a arbitragem adquire especial importância. Aí se exige, ao intérprete/julgador, conhecimentos

300 Vide PAMBOUKIS, Ch. - La Lex mercatoria reconsidéré. Le droit internacional privé : esprit et méthodes. Melanges Paul Lagarde. Paris, Dalloz, 2005, pág. 619.

301 Vide STRENGER, Irineu - Direito do Comércio Internacional e Lex Mercatoria. São Paulo, LTr., 1996, págs. 70-71.

${ }^{302}$ Vide GOTTWALD, Peter - Internationale Schiedsgerichtsbarkeit. in Internationale Schiedsgerichtsbarkeit, org., por Peter GOTTWALD (CIT.) 3-160, 1997.pág. 3. Vide também. RECHSTEINER, Beat Walter. - A arbitragem privada internacional no Brasil. São Paulo, RT, 2001, pág. 25; RECHSTEINER, Beat Walter. - Direito internacional privado: teoria e prática. 6. ed. São Paulo, Saraiva, 2003. GARCEZ, José Maria Rossani. - Negociação, ADRs, Mediação e Arbitragem. Rio de Janeiro, Ed. Lúmen Júris, 2003, pág.71. Cerca de $80 \%$ dos conflitos mercantis são dirimidos por via arbitral.

303 A par do transporte marítimo e na indústria do petróleo. In ibidem. Vide RECHSTEINER, Walter Beat. - Arbitragem privada internacional no Brasil: depois da nova lei 9.307, de 23.09.1996: Teoria e prática. 2. ${ }^{a}$ Ed., São Paulo, Revista dos Tribunais, 2001. ${ }^{304}$ Ademais e segundo o Secretário do Tribunal de Arbitragem da CCI - relativamente às arbitragens CCI - estima-se que $90 \%$ das decisões arbitrais são executadas voluntariamente. CRAIG; PARK; PAULSSON - Annotated Guide to the 1998 ICC Arbitration Rules, Oceana Publications, 1998, págs. 343, 404. Para o efeito, também, contribuiu, o controlo prévio do laudo arbitral, que por sua vez eleva a reputação do procedimento arbitral da CCI. 
muito específicos, a par das consequências inerentes à transnacionalização dos contratos mercantis ${ }^{305}$.

Em geral, os conflitos emergentes das relações jurídicas transnacionais exigem soluções pelo menos "eficazes e sumamente velozes." Não esqueçamos que leis justas, não são suficientes para a criação de grandes nações. Também se impõe uma justiça rápida e pouco onerosa, sob pena de efetividade da justiça representar letra morta ${ }^{306} 307$.

São imensos os instrumentos internacionais que revelam a importância da lex mercatoria como instrumento capaz de responder às necessidades e interesses dos operadores do comércio internacional ${ }^{308}$.

\section{OS PRINCÍPIOS GERAIS DE DIREITO COMUNS ÀS NAÇÕES CIVILIZADAS, EM ESPECIAL EM MATÉRIA CONTRATUAL}

Os princípios gerais de direito comuns às "nações civilizadas" assumem grande relevo em sede da contratação internacional ${ }^{309}{ }^{310}$. Po-

305 Vide. SZKLAROWKSY, Leon. - Arbitragem Marítima. In Revista Jurídica Consulex - Ano XII - n. ${ }^{\circ} 277$ - 31 de Julho de 2008. In passim Disponível em: http://www.2ccago.com.br/up/arbitragem.pdf. Acesso em: 03/03/2012.

306 In ibidem.

${ }^{307}$ Entendemos que o aspeto da onerosidade deverá ser ponderado com as implicações da prolação da decisão judicial pelo Tribunal Estatal e consequente desgaste da relação entre os contratantes e o aumento do grau de afetação dos contratos paralelos. Porque nem sempre os gastos nas instâncias arbitrais p. ex. os honorários dos árbitros designados serão inferiores aos custos inerentes ao funcionamento da máquina judiciária Estatal. Todavia, poderão constituir uma segurança, pela eficiência. Contudo, a arbitragem ad hoc, em detrimento da institucional, deverá ser menos onerosa tendo em linha de comparação o valor das taxas administrativas pagas.

308 A Convenção para a Resolução de Diferendos relativos a Investimentos entre Estados, de 18 de Março de 1965, art. 42 n. ${ }^{\circ}$ 1: "O tribunal julgará o diferendo em conformidade com as regras de direito acordadas pelas partes. Na ausência de tal acordo, o tribunal deverá aplicar a lei do Estado contratante, parte no diferendo (também as regras conflituais), bem como os princípios de Direito Internacional aplicáveis."; A lei modelo da CNUDCI, art. 28. ${ }^{\circ}$ n. ${ }^{\circ}$, "em qualquer caso, o tribunal arbitral decidirá de acordo com as estipulações do contrato e terá em conta os usos do comércio aplicáveis à transação."; a Convenção de Viena de 1980 sobre os Contratos de Compra e Venda Internacional de Mercadorias, art. 9. ${ }^{\circ}$; o Regulamento de Arbitragem CNUDCI, no art. 17 n. 2 (...)

${ }^{309}$ Segundo Lando, e com um certo grau de ambiguidade, seriam os princípios gerais de direito reconhecidos pelas nações comerciantes. LANDO, O. - The Law Applicable to 
demos entendê-los como um procedimento de heterointegração positiva, assumindo-se, desta forma, a unidade sistemática da lex mercatoria. Exemplos elucidativos são: liberdade contratual, boa-fé, pacta sunt servanda, venire contra factum proprium non valet, restitutio in integrum, culpa in contrahendo, qui tacet consentire videtur, a cláusula rebus sic stantibus, exceptio non adimplenti contractus, dever de limitar os danos [também, proibição do enriquecimento sem causa, não execução de contratos e cláusulas gerais desleais ou injustas, o favor negoti] $(. . .)^{311312}$.

Não esqueçamos a sua importância como diretrizes para qualquer ordem jurídica, como fundamentos e limites às suas normas jurídicas. Esse é o papel dos princípios gerais de direito, influenciando na elaboração das normas jurídicas e auxiliando no processo de integração do direito. ${ }^{313}$ São gerais, porque se tratam de princípios que direcionam o direito como um todo, todavia, também podem ser específicos de um outro ramo ou sector do direito. Desta forma, farão parte da realidade dinâmica objeto do presente estudo.

Gostaríamos de sublinhar a importância e dimensão global que os princípios gerais de direito, especialmente em sede contratual, ganharam nas últimas duas décadas.

the Merits of the Dispute, in: SARCEVIC (ed.), Essays on International Commercial Arbitration. Boston, London, 1991, pág. 146. Disponível em http://tldb.uni-koeln.de. Consultado em 14-03-2015.

${ }^{310}$ Os princípios Gerais de Direito da Lex mercatoria estão ligados à noção de bona fides. Constitui uma regra de interpretação, guia do processo, estando presente na maioria das sentenças arbitrais. HORSMANS, Guy. - L'interprétation des contrats internationaux, in L'apport de la jurisprudence arbitrale: Séminaire des 7 et 8 avril 1986 (ICC Publishing S.A.), 1986, pág. 153.

${ }^{311}$ Permitindo dotar a nova lex mercatoria de uma estrutura mais consistente permitindolhe atingir a universalidade. VIRALLY, M. - Un tiers droit? Réflexions théoriques, in le droit des relations économiques internationales, in Études offertes à Berthold Goldman, Litec, Paris, 1987, pág. 384.

312 Acerca destes princípios, A. GONÇALVES PEREIRA- Fausto de QUADROS, -

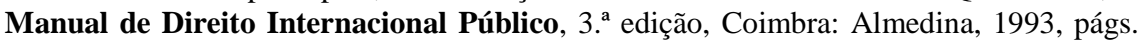
257 e ss., especialmente pág. 262.

313 A título de curiosidade, "Fonte de inspiração" para o TJUE. Vide EUROPA>Sínteses da legislação da UE>Assuntos institucionais>-As fontes não escritas do direito europeu: direito subsidiário, Disponível em:

http://europa.eu/legislation_summaries/institutional_affairs/decisionmaking_process/1145 33_pt.htm Consultado em: 18-02-2015 
O princípio geral paradigma é, sem dúvida, o pacta sunt servanda, plasmado no artigo 26..$^{\circ}$ da Convenção de Viena Sobre o Direito dos Tratados, de 23 de Maio de 1969 e da Convenção de Viena Sobre o Direito dos Tratados entre Estados e Organizações Internacionais ou entre Organizações Internacionais, de 21 de Março de 1986, articulado com o art. 38 n. $^{\circ}$, al. c) do Estatuto do Tribunal Internacional de Justiça. De costume de Direito Internacional Público passou a princípio geral de direito positivo. Penetrando com força obrigatória nos ordenamentos jurídicos nacionais. Inspirando os legisladores nacionais que à luz das suas decorrências disciplinam os aspetos essenciais das obrigações.

Como se compreenderá, a sua subjetivação não trouxe nada de novo ao tão afamado acordo de cavalheiros da prática negocial, apenas uma concretização objetiva do principio da boa fé (que apresenta uma natureza corretiva), cuja importância remonta ao direito natural. A acuidade daquele acordo, a par do valor reconhecido à palavra (entenda-se palavra de cavalheiros), está na base do valor atribuído à autonomia privada em sede contratual, que, consequentemente, acentua a carga icônica atribuída ao contrato.

A Autonomia privada revela-se como "princípio característico do Direito Civil" e por decorrência necessária de outros ramos do direito privado, como o direito comercial. Traduz um afloramento do princípio da liberdade, segundo o qual é lícito tudo o que não for proibido (art. 4 . $^{\circ}$ da Declaração de 1789), que tem como contraposição o princípio da competência (a licitude depende da permissão) imperante no direito Público. Pelo que o seu nível de reconhecimento é "um dos traços reveladores da fisionomia de cada sistema jurídico" 314.

Este princípio tem como principal projeção a liberdade de contratar, no plano negocial, pelo fato de relevar a figura do contrato ${ }^{315}$ sob a égide das seguintes forças: "o valor da nuda pacta" ("ensinamentos dos canonistas"); "pacta sunt servanda"("antigos canonistas") (...); "solus consensus obligat” (escola jusracionalista) (...) o que reforçou "a supre-

\footnotetext{
${ }^{314}$ FERNANDES, Luís A. Carvalho, - Teoria Geral do Direito Civil -Vol. I - Introdução; Pressupostos da Relação Jurídica, 5 Edição, Universidade Católica, 2009, pág. 94.

315 Facto que terá influído na consagração, entre nós, do princípio da autonomia privada "no domínio do Direito das Obrigações, no artigo. $405 .^{\circ}$ do C.Civ português; mas também no diploma constitucional ele encontra referências, quando nele se reconhecem a iniciativa económica privada, ainda que sem perder de vista o interesse geral (arts. $61 .^{\circ}, \mathrm{n} .^{\circ} 1$, e $82 .^{\circ}, \mathrm{n} .{ }^{\circ} \mathrm{s} 1 \mathrm{e}$ 3), e a livre escolha de profissão, ou género de trabalho [art.s $47 .^{\circ}$ e $58 .^{\circ}$, n..$^{\circ}$,al.b)]". Ibidem, pág. 96
} 
macia da vontade esclarecida do homem sobre as forças criadoras do direito", e permitiu espiritualizar o contrato; o voluntarismo jurídico (influência da burguesia triunfante [nos momentos históricos] ${ }^{316}$. Contudo, também se aflora no "domínio dos direitos subjetivos", âmbito em que o princípio da autonomia expressa "o poder de livre exercício dos direitos pelo seu titular". Liberdade, "que encontra o seu paradigma no direito de propriedade", conteudisticamente falando, não totalmente ilimitada ${ }^{317}$.

Encontramos uma forte correspondência dos princípios gerais de direito reconhecidos pelas nações comerciantes com determinados sistemas de regras e princípios codificados por estruturas organizativas de natureza semipública, designadamente os princípios de UNIDROIT (Instituto Internacional para a Unificação do Direito privado $\left.{ }^{\mathbf{3 1 8}}\right)(1995,2004$, 2010), para os contratos do comércio internacional ${ }^{319} 320321$. Aliás, decorre do preâmbulo desse instrumento uma unidade valorativa de sentido, quando no $3 .^{\circ}$ parágrafo, concretiza que " caso as partes tenham acordado que o seu contrato será regulado por princípios gerais de direito, pela lex mercatoria, ou similares" 322323 o tratado UNIDROIT tem, de fato, aplicação efetiva. Integra-se essa unidade de sentido com o grau de eficiência e

\footnotetext{
316 Vide ANTUNES VARELA, João de Matos, - Das Obrigações em Geral, Vol. I, 10. ${ }^{2}$ Edição, Almedina, (5. Reimpressão da Edição de 2000), págs. 211-218

317 Vide FERNANDES, Luís A. Carvalho, - Teoria Geral do Direito Civil, ob cit., pág.. 94 318 Organização intergovernamental independente, na atualidade, com 63 Estados membros. Vide. Site disponível em: http://www.unidroit.org/about-unidroit/membership. Consultado em: 16-05-2015.

${ }^{319}$ No mesmo sentido Vide. BERGER, Klaus Peter - The Lex Mercatoria Doctrine and the UNIDROIT Principles of International Commercial Contracts. In: Law and Policy in International Business. 1997, págs. 943-990. Disponível em: http://www.questia.com/PM.qst?a=o\&d=5001524029. Consultado em: 14-03-2015.

320 Vide os comentários. VV.AA. - Comentários a los Princípios de Unidroit para los Contratos del Comercio Internacional. Pamplona: Aranzadi, 2. edição, 2003

${ }^{321}$ A propósito do contrato internacional de engenharia, mais concretamente, a ausência de um direito convencional material uniforme nessa matéria, poderia explicar-se o desenvolvimento pelos comerciantes da lex mercatoria. FRIGNANI, A. - Il contrato internazzionale, Trattato di diritto commerciale e di diritto pubblico dell'economia diretto da Francesco Galgano, vol. XII, Padova, 1990, pág. 10.

322 Princípios UNIDROIT relativos aos contratos comerciais internacionais 2010. Translation by Professor Lauro Gama, Jr. (Professor of Law, Catholic University of Rio de Janeiro PUC-RIO; Senior Partner, Binenbojm, Gama \& Carvalho Britto Advogados; Member of the Working Group for the preparation of the UNIDROIT Principles of International Commercial Contracts).

${ }^{323}$ Comentário ao Preâmbulo [n. ${ }^{\circ} 4^{\circ}$ a]
} 
previsibilidade que brota do $4 .^{\circ}$ parágrafo, quando o tratado se posiciona na qualidade de modelo de aplicação subsidiária na falta de escolha pelas partes e, por maioria de razão, quando, por outras razões, não seja possível determinar o critério da lei aplicável ao caso ${ }^{324}$.

A sua primeira edição foi aprovada pelo Conselho de Direção do UNIDROIT (Instituto Internacional para a Unificação do Direito Privado, com sede em Roma) no ano de 1994, e publicada em diversas línguas (espanhol, italiano, francês, inglês, alemão, e uma versão em língua portuguesa publicada pelo Ministério da Justiça) ${ }^{325326}$ que, para além das disposições gerais, incluía regras sobre a formação, interpretação, conteúdo, validade, o cumprimento e incumprimento. Na sua segunda edição, aprovada em Abril de 2004, foram acrescentados cinco capítulos sobre a representação, o contrato a favor de terceiro, compensação, assunção de dívidas, cessão de créditos e transmissão da posição contratual e a prescrição $^{327}$. Já na sua terceira edição acrescentaram-se disposições sobre a restituição no caso de contratações frustradas, ilegalidade, condições, e pluralidade de devedores e de credores, e algumas alterações aos comentários feitos ao artigo 1.4 da 2 . $^{\mathrm{a}}$ edição.

Em termos histórico-jurídicos o tratado, ora em estudo, constitui um verdadeiro sistema de princípios, regras, e critérios ou soluções jurídicas que um grande grupo de especialistas ${ }^{328} 329$, pertencentes a culturas jurídicas e a experiências profissionais várias ${ }^{330}$, entendeu serem comuns aos principais sistemas jurídicos nacionais (senão a todos) e mais adequa-

\footnotetext{
${ }^{324}$ Comentário ao Preâmbulo [n. ${ }^{\circ} 4$ a, c] e parágrafos n. ${ }^{\circ}$ s 2, 3, 4 e 8 do Preâmbulo.

325 Vide Princípios Relativos aos Contratos Comerciais Internacionais, versão provisória em língua portuguesa, (Lisboa), Ministério da Justiça, 2000.

${ }^{326} \mathrm{Na} \mathrm{3.}{ }^{a}$ edição contamos com uma versão oficial em português. "Translation by Professor Lauro Gama, Jr. (Professor of Law, Catholic University of Rio de Janeiro PUC-RIO; Senior Partner, Binenbojm, Gama \& Carvalho Britto Advogados; Member of the Working Group for the preparation of the UNIDROIT Principles of International Commercial Contracts)." Disponível em: http://www.unidroit.org/english/principles/contracts/principles2010/translations/blacklette r2010-portuguese.pdf

${ }^{327}$ BONELL, M. J. - The New Edition of the Principles of International Commercial Contracts adopted by the International Institute for the Unification of Private Law, Uniform Law R. 9: 5-40. 2004.

${ }^{328}$ Académicos, magistrados, advogados etc.

${ }^{329}$ O denominado Professorenrecht (Direito dos professores).

330 Prologo à edição de 1994
} 
dos "às exigências do comércio internacional"331 332. "Nalguns pontos (...) propõem-se soluções consideradas pelos seus autores como as melhores, mesmo que não sejam as mais praticadas" ${ }^{333}$, revelando-se inovadores, em alguns domínios 334335 .

Sendo, deveras, aconselhável, quando se elege o presente instrumento como regulador do contrato, a aposição de uma cláusula de acordo arbitral, no sentido de transcender, eficazmente, o contrato das amarras dos direitos nacionais ${ }^{336}$.

O Conselho de Administração do instituto delibera avançar com o projeto de unificação em estudo no ano de $1971^{337}$.Um comitê piloto composto pelos professores René David, Clive M. Tudor Popescu Schmitthoff, representando os sistemas de tradição jurídico romanística, de Common Law, e os países socialistas, fora responsável pela realização de estudos preliminares sobre a possibilidade de um projeto com estas características. Já em 1980, é estabelecido um grupo de trabalho especial para proceder à escrita dos projetos de capítulos. O grupo, composto por representantes dos principais sistemas jurídicos do mundo, era composto por

\footnotetext{
${ }^{331}$ Comentário ao Preâmbulo (n. ${ }^{\circ} 4$ a). $2 .^{\text {a }}$ Edição.
}

332 "Foi dada especial atenção às codificações mais recentes (o "Uniform Commercial Code" e o "Restatement of the law of contracts" dos Estados Unidos, o Código Civil argelino de 1975, a lei chinesa de direito contratual económico estrangeiro e os trabalhos preparatórios do Código Civil holandês e do Québec) e, a nível international, à "United Nations Convention on Contracts for the International Sale of Goods" (a seguir: "CISG") e a instrumentos de auto-regulação de utilização muito difundida." In PEREIRA, Teresa Silva - Proposta de reflexão sobre um Código Civil Europeu, Artigos doutrinais da Ordem Dos Advogados, Publicações > Revista > Ano 2004 > Ano 64 - Vol. I / II - Nov. 2004, (I.1.2. Fontes) Disponível em:http://www.oa.pt/Conteudos/Artigos/detalhe_artigo.aspx?idc=31559\&idsc=45841\&id $\mathrm{a}=47182$. Consultado em: 19-02-2015. (Negrito nosso)

${ }^{333}$ In RAPOSO, Mário - Temas de arbitragem comercial [Lex Mercatoria], ob. cit..

${ }^{334}$ In ibidem. [I.1.5. Conteúdo].

${ }^{335}$ Incluiu fórmulas como: hardship ou à gross disparity. Vide SERAGLINI, Christophe Du bon usage des principes Unidroit dans l'arbitrage international, na Rev.Arb., 2003, págs. 1101 - 1166, em especial, pág. 1104.

${ }^{336}$ No mesmo sentido Comentário ao Preâmbulo [n. ${ }^{\circ} 4$ a]

${ }^{337}$ Incluiu na mesa de trabalhos um "essai d'unification portant sur la partie générale des contrats (en vue d'une codification progressive du droit des obligations 'Ex contractu')" UNIDROIT 1971, C.D. 50. a Sessão, pág. 93; A ideia inicial terá surgido na comemoração dos 40 anos do UNIDROIT. Vide BONELL, Michael Joachim - The UNIDROIT Initiative for the Progressive Codification of International Trade Law, The International and Comparative Law Quarterly, 1978, pág. 413. 
especialistas de renome no domínio do direito dos contratos e, também, do direito do comércio internacional. O grupo nomeou os escritores dos diferentes capítulos dos Princípios, encarregando-os de apresentar os projetos e os comentários. Esses projetos foram discutidos pelo grupo e remetidos a especialistas, incluindo numerosos correspondentes de UNIDROIT em todo o mundo. Para além do mais, o Conselho deu o seu parecer sobre a política a seguir, especialmente nos assuntos de difícil consenso. Os trabalhos ficaram concluídos em Fevereiro de 1994 e em Maio do mesmo ano, o texto fora remetido para aprovação ao corpo científico máximo do Instituto ${ }^{338}$. "Os Princípios foram, finalmente, publicados sob direção do Professor Michael Joachim Bonell” ${ }^{339}$. A Comissão de redação tem sido responsável pelo trabalho editorial, assistida pela secreta$\mathrm{ria}^{340}$.

O objetivo fundamental destes princípios é de estabelecer um conjunto de regras a serem utilizadas em todo o mundo independentemente das específicas tradições jurídicas, condições econômicas e políticas dos países. Nesta linha de raciocínio, fita a universalidade ${ }^{341}$.

Reconhecem a liberdade contratual, os usos, o favor contractus, boa-fé objetiva e o "fair dealing", e promovem o combate à injustiça contratual $^{342}$.

Os Princípios UNIDROIT demonstram o seu intrínseco cariz transnacional, pelo fato de não recorrerem a uma terminologia própria de um sistema jurídico determinado. Os comentários que acompanham cada disposição não fazem referência aos direitos nacionais para explicar a solução jurídica acolhida (somente quando reproduzem a CISG - Convenção das Nações Unidas sobre os Contratos de Venda Internacional de Mercadorias) ${ }^{343}$.

No concernente às questões de mérito os Princípios são flexíveis o suficiente para se adaptarem a eventuais - mas inevitáveis - mudanças na prática comercial transnacional, fruto do desenvolvimento tec-

\footnotetext{
${ }^{338}$ In PEREIRA, Teresa Silva - Proposta de reflexão sobre um Código Civil Europeu, ob cit.

${ }^{339}$ In ibidem e obra citada.

340 Prologo à edição de 1994

${ }^{341}$ In ibidem.

${ }^{342}$ Respetivamente: 1.1; 1.9; p. ex. 7.3 .1 (1); 1.7; e, entre outros, 7.1.6 / 7.1.7 (1) dos

Princípios UNIDROIT 2010.

${ }^{343}$ In ibidem.
} 
nológico e econômico, das flutuações financeiras e repercussões no mundo dos negócios em geral. Característica bastando a constatação de que se revelam, transparentemente, abertos aos usos e costumes do comércio transnacional (art. 1.9 dos Princípios UNIDROIT). Simultaneamente procuram assegurar a equidade nessas relações estabelecendo, o dever das partes atuarem segundo os ditames da boa-fé, impondo, em alguns casos, critérios de razoabilidade.

Trata-se de um instrumento que, por um lado, não carece de ser aprovado ou ratificado pelos Estados de forma a permitir disciplinar os contratos transnacionais, por outro lado não reveste natureza de hard law, ao invés caracteriza-se como soft law, droit assourdi, ou direito flexível.

Tendo em linha de conta o texto introdutório feito à edição de 2004, "os Princípios UNIDROIT foram acolhidos favoravelmente na prática não dando lugar a particulares dificuldades na sua aplicação", isto, segundo a "casuística" e a bibliografia da base de dados UNILEX ${ }^{344}$. Pelo que, se procedeu à sua ampliação.

De acordo com o texto de introdução à edição de 1994 a iniciativa de UNIDROIT para a criação dos Princípios sobre os contratos de comércio internacional vai no sentido de elaborar um restatement internacional $^{345}$.

Segundo Lima Pinheiro os Princípios não constituem uma codificação privada da lex mercatoria ${ }^{346}$ ou algo de comparável aos restatement "jurisprudencial (arbitral), seja na dita visão tradicional ou moderna." Para esta, aquele não se limitava à sistematização do direito jurisprudêncial, como naquela visão, antes corresponderia à "opinião qualificada de alguns dos mais eminentes académicos sobre o Direito que deve ser aplicado atualmente por um tribunal esclarecido ${ }^{347}$."

No entendimento do Professor, estes Princípios também não poderiam ser considerados "restatement do direito dos contratos à escala mundial, uma vez que a pluralidade de sistemas jurídicos nacionais é incompatível com uma consolidação universal ${ }^{348}$." Atenta, por um lado, o grau de independência dos sistemas jurídicos e à heterogeneidade das soluções jurídicas apresentadas por estes, e, por outro lado, em matéria de

\footnotetext{
344 Vide UNILEX. Disponível em: «www.unilex.info».

${ }^{345}$ Vide Introdução à Edição de 1994 na 2. ${ }^{\text {a }}$ edição dos Princípios da UNIDROIT.

${ }^{346}$ Em sentido diferente, do qual partilhamos, pelo menos parcialmente.

${ }^{347}$ LIMA PINHEIRO - Direito Comercial Internacional, ob. cit., pág. 195.

${ }^{348}$ In ibidem, pág. 196
} 
contratos de comércio internacional o fato de também vigorarem "regras e princípios autônomos de direito transnacional que podem divergir, em maior ou menor medida, das soluções nacionais."

Não obstante a bondade dos argumentos, entendemos, salvo o devido respeito, que para compreender o intrínseco sentido da expressão e, concomitante, finalidade, direta e indireta, destes Princípios, em forma de tratado, devemos apelar a uma especial sensibilidade, pois eles condensam, em si, parte de uma realidade jurídica única, suis generis, constituída, diga-se por todo um conjunto de princípios, regras, no fundo, critérios jurídico-normativos de cariz negocial, edificados no respeito por determinados carateres jurídicos e econômicos essenciais, que aproveitamos por denominar de valores mercantis de vocação universal, que não podem, de todo, ser ignorados. Passamos a expor:

- A perspetiva transnacional;

- A supranacionalização do contrato transnacional;

- A eficiência e a universalidade;

- Respeito pelas exigências do comércio transnacional e pela prática dos seus operadores $^{349}$;

- Relevância para o comércio transnacional da unificação de determinados critérios jurídicos;

- Importância de se promover a uma inovação na estrutura da lex mercatoria , dando-lhe uma solidez que até então não se afigurara muito clara ${ }^{350}$.

Como quaisquer outros valores norteadores revelam-se no binômio fundamento/limite (densificação), sobretudo no plano normativolegislativo, mas, também, no momento decisório. Em particular, nas questões de racionalidade jurídica e econômica, manifesta-se em tudo consonante com o modus de funcionamento do comércio internacional e com o processo legislativo nacional e internacional, assim:

- Recorrendo a um método flexível, dominar a opinião jurídica através do jogo de influência nos sistemas nacionais e no internacional, podendo servir de modelo jurídico de regulação ${ }^{351}$;

\footnotetext{
${ }^{349}$ Servindo de guia de regulação contratual. In CALVO CARAVACA, A. L.; CARRASCOSA GONZÁLEZ, J., - Curso de Contratación Internacional. Madrid, Editorial Colex, 2003. págs. $55-56$.

350 Não esqueçamos as vezes que ela é mencionada no diploma. Desde o Preâmbulo (3. ${ }^{\circ}$ parágrafo), nos comentários [4 b] na 2. ${ }^{\mathrm{a}}$ edição (...), e no art. 1.9.
} 
- Disponibilizar-se como mecanismo interpretativo e integrativo dos instrumentos internacionais de direito uniforme e dos direitos nacionais, servindo, também, aos tribunais judiciais ${ }^{352}$ e arbitrais $^{353}$;

- Estabelecimento de critério de retidão comportamental dos operadores mercantis.

Em especial nas questões da arbitragem:

- Poder constituir o "sistema jurídico" do contrato comercial transnacional;

- Traduz uma fonte de equidade ${ }^{354}$.

Desta forma, estes Princípios, consolidam e sistematizam, ainda que não por forma integral ou absoluta, alguns dos princípios e regras estruturantes, da nova lex mercatoria, fundamentalmente, a boa-fé - cujos padrões jurídicos decorrentes deverão ser encarados como quadros objetivos codicionantes, numa perspetiva fundamental de razoabilidade normativa $^{355}$ - e as suas principais manifestações, que adquirem, assim, uma nova natureza, mais evoluída. ${ }^{356}$

Ainda que estes princípios não se autoproclamem lex mercatoria denominam-se de direito anacional ou supra nacional (atente-se a sua visão transnacional do comércio) ${ }^{357}$.

\footnotetext{
${ }^{351}$ Preâmbulo n. ${ }^{\circ}$ 7, Vide, também, comentário [7]

352 Ressalvando que as partes terão acolhido no respetivo instrumento contratual.

${ }^{353}$ Preâmbulo n. ${ }^{\circ} 5$ e 6, Vide, também, comentário [4c, 5, 6 e 8]

${ }^{354}$ In CALVO CARAVACA, A. L.; CARRASCOSA GONZÁlEZ, J., - Curso de Contratación Internacional. $o b$ cit. págs. 55-56.

${ }^{355}$ Neste sentido. Vide. QUEIROZ, Everardo Nóbrega de - O princípio da razoabilidade na Nova Lex Mercatoria, Tese de Doutoramento, FFLCH-USP, 2000.

${ }^{356} \mathrm{O}$ entendimento de que a nova lex mercatoria seria, apenas, direito espontâneo gerado pelos operadores do comércio transnacional à revelia dos direitos nacionais, já não colhe na sua totalidade, visto que essa espontaneidade não permitiria a criação de um Direito que a partir de si ganhasse aplicabilidade efetiva. «[c]omo diz Eric Loquin(...) a nova lex mercatoria vai absorvendo normas provindas de fontes convencionais. A lex mercatoria "é menos uma lista de regras que uma selecção de regras"(...). E muitas dessas regras provêm de outras fontes que o mero direito espontâneo gerado pelos operadores de comércio internacional.» In RAPOSO, Mário - Temas de arbitragem comercial [Lex Mercatoria, Início> Publicações >Revista > Ano $2006>$ Ano 66 - Vol. I - Jan. 2006 > Doutrina.

Disponível

em: http://www.oa.pt/Conteudos/Artigos/detalhe_artigo.aspx?idc=31559\&idsc=47773\&ida=4 7824

357 Vide comentário ao Preâmbulo [4c]
} 
Não esqueçamos, que a nova lex mercatoria assimilara no decurso dos tempos alguns princípios que constituíram norte de ação para as regras da prática mercantil, que em nosso entender, traduzem, claras manifestações do direito natural ${ }^{358} 359{ }^{360}$,por contraposição com o direito considerado "[a]rtificial" (ainda que legítimo).

Bastará refletir sobre a expressão "acordo de cavalheiros", questionar onde foi beber o critério retor fundamental e deparamo-nos que, na verdade, não mais é que uma feliz manifestação do princípio da boa-fé, nos seus corolários, como o pacta sunt servanda, a importância também reconhecida à autonomia da vontade, (...) Pelo que, em bom rigor, ainda que indiretamente, os princípios UNIDROIT terão condensado alguns dos princípios base participantes do processo de "heterointegração" jurídica desta realidade, que, efetivamente, no decurso dos anos, apesar do seu corpo, dimensão e diversidade, têm ganhado um peso e estrutura cada vez mais vincados [muito, também, graças ao labor do Instituto UNIDROIT e outros organismos privados].

\footnotetext{
${ }^{358}$ Sobre o Direito Natural Vide. ELLSCHEEID, - O problema do direito natural. Uma orientação sistemática, in KAUFMANN/HASSEMER (Eds), - Introdução à Filosofia do Direito e à Teoria do Direito Contemporâneas (trad. port.), Lisboa, 2002, págs 211 e ss.
}

359 Segundo CASTRO MENDES, “direito que devia vigorar (...) aquele núcleo que devia valer como direito em qualquer sociedade humana." In CASTRO MENDES, J. -


25.

${ }^{360}$ Sobre a noção de direito natural, já, Cícero considera existir "uma lei verdadeira, que é a reta razão, que concorda com a natureza, difusa em todos, imutável e eterna; que nos reclama imperiosamente o cumprimento dos nossos deveres e que nos proíbe a fraude e nos afasta dela; cujos preceitos e proibições o homem bom (honestus) acatará sempre, enquanto que os perversos lhe serão surdos. Qualquer correção a esta lei será sacrílega, não sendo permitido revogar alguma das suas partes; não podemos ser dispensados dela nem pelo Senado nem pelo povo; não é necessário encontrar um Sextus Aelius para a interpretar; esta lei não é uma em Atenas e outra em Roma; mas é a única e mesma lei, imutável, eterna e que abrange em todos os tempos todas as nações. Um Deus único, senhor e imperador de todas as coisas, por si só, imaginou-a, deliberou-a e promulgou-a [...]". In HESPANHA, António Manuel, - Cultura Jurídica Europeia, Síntese de um milénio, Coimbra, Almedina, 2015, pág. 210, nota 347.

A doutrina do Direito natural carateriza-se por um, intenso, dualismo fundamental entre Direito positivo e Direito natural. O Direito natural, ou Direito absolutamente justo, posicionado acima do imperfeito Direito positivo fundamentando a validade deste. Nesta medida, aquele dualismo entre assemelha-se ao "dualismo metafísico da realidade e a ideia platónica."In KELSEN, Hans. Teoria geral do direito e do estado. 3. ed. Tradução de Luís Carlos Borges, São Paulo, Martins Fontes, 1998, pág. 17. 
Consideramos os princípios UNIDROIT uma feliz ilustração dos afloramentos mercantis no mundo. Não olvidemos, também, o passado. O período do positivismo exacerbado, que culminou com a codificação da lex mercatória, permitiu solidificar uma realidade dinâmica, e nessa tentativa, certamente resultaram resquícios fundamentais, que, seguramente, agora constituem pilares, estruturantes, do direito civil e em especial do direito comercial.

Os restantes critérios, referimo-nos àqueles mais desenvolvidos, mais específicos, interpenetram a estrutura da lex mercatória através das práticas mercantis - se e quando os mercadores os incorporam, total ou parcialmente, nos seus contratos, potenciando a criação de costume transnacional - e da jurisprudência arbitral - tendo em conta o prestígio e adequação daqueles, servirão de base às decisões arbitrais, quando aplicáveis, permitindo, em última linha, a criação de costume jurisprudencial florescendo, assim, da base do comércio transnacional ${ }^{361} 362$.

Não podemos ignorar o caráter flexível deste direito, que, por um lado, potencia a aceitação das diversas opiniões jurídicas globais e por outro lado evita choques irreversíveis, ou, mais corretamente, evita os obstáculos à harmonização de critérios.

Consideramos, também, que a base fundamental destes critérios são princípios gerais ou abstratos, que por natureza são flexíveis, elásticos e, nesta medida, admitem contradição, sanável pela articulação ou harmonização de critérios jurídicos.

É verdade, no entanto, que na Commonwealth e, mesmo, noutros sistemas jurídicos, princípios como o da Boa-fé, ex maxime, pode desempenhar a mesma função em termos contratuais que nos diversos ordenamentos jurídicos dos países romano-germânicos, desconsiderando, no que tange a estes últimos, situações que em princípio subsumir-se-iam, em abstrato, nas condutas contrárias àquele princípio. Todavia, há que atender, mais uma vez, ao caráter transnacional dos princípios, e perder a

\footnotetext{
${ }^{361}$ Um raciocínio semelhante. LIMA PINHEIRO - Direito Comercial Internacional, $o b$ cit. págs. $196-197$

362 Para tal Vide OLIVEIRA ASCENÇÃO - O direito. introdução e teoria geral, 13. ${ }^{\text {a }}$ edição, lisboa, 2005, pág. 324; REHBINDE, Manfred - Einführung in die rechtswissenschaft. 6. ${ }^{a}$ edição do manual de B. Rehfeldt, Berlim e Nova Iorque. 1988, pág. 13; LARENZ, K. - Methodenlehre der rechtswissenschaft, 6. ${ }^{a}$ edição, berlim et. al. 1991, pág. 433; LARENZ, Karl/ CANARIS, Claus-Wilhelm, - Methodenlehre der rechtswissenschaft, 3. ${ }^{a}$ edição, berlim et al., 1995, pág. 258 e ss. Comparar com. STEIN, Ursula, - Lex mercatoria, ob. cit., págs. 162 e ss. e 175 e ss.
} 
ligação aos nacionalismos, pois, se a tal nos apelar o contrato, já não estaremos a falar de um com uma natureza verdadeiramente transnacional, mas, por ventura, transfronteiriça, em relação ao qual alguns carateres poderão sugerir a aplicação de princípios ou regras de direito nacional, seja por via direta ou indireta. Contudo, não esqueçamos o caráter integrativo dos Princípios UNIDROIT que, concomitantemente, não se impõem, podendo servir de modelo orientativo para as partes e para o intérprete / julgador. Finalmente, atentemos para a sua natureza equitativa, direcionada para os interesses, necessidades dos operadores do comércio transnacional.

Quanto às regras jurídicas ou critérios práticos de outras fontes da nova lex mercatoria, ainda que divergentes das destes Princípios, ajustar-se-ão a necessidades específicas dos diversos setores mercantis, e dentro desses setores às especificidades de certos contratos comerciais transnacionais. Não consideramos a diversidade, que carateriza os elementos constitutivos da lex mercatoria, um fator limitativo e/ou desintegrativo; entendêmo-lo, antes, como um instrumento ao serviço de uma construção autopoietica de um corpo de soluções para uma realidade multifacetada e dinâmica, que é, sem dúvida, a contratação internacional.

Como teremos oportunidade de demonstrar, diversas são as pontes de interceção entre os princípios UNIDROIT e os Princípios do Direito Europeu dos Contratos (PECL) $(1990,1995,1999,2003)^{363}$.

Desde logo, parte dos membros do UNIDROIT participaram na Comissão ad hoc denominada de Lando $^{364}$ (Comissão sobre o Direito Europeu dos Contratos), pelo que existe uma certa coordenação entre estes grupos ${ }^{365}$, sem que exista, no entanto, uma latente concorrência entre os critérios jurídicos produzidos ${ }^{366}$.

\footnotetext{
${ }^{363}$ Instrumento (núcleo duro), ora, integrado no Quadro Comum de Referência (QCR).

${ }^{364}$ Formou-se sob o seu impulso, apoiado pela Comissão CE (agora UE) e um conjunto de particulares. Vide, LANDO,O. / BEALE, Hugh, - The Principles of European Contract Law, Dordrecht, Boston e Londres, 1995. ix e ss. e LANDO, O. (ORG.), - Principles of European Contract Law. Parts I \& II Combined and Revised, Dordrecht, Boston e Londres, 2000; The Principles of European Contract Law and the lex mercatoria, in Private Law in the International Arena. Liber Amicorum Kurt Siehr, 391-404, A Haia, 2000; LANDO, O. - Principles of European Contract Law. An Alternative or a Precursor of European Legislation, Rabels Z. 56: 261-273. 1992.

${ }^{665}$ Desta forma, os presidentes, assim como Denis Tallon e Ulrich Drodnig.

366 "[T] he two instruments in actual practice not only do not overlap but may well coexist and play equally important, but not interchan-geable, roles". BONELL, Michael Joachim,
} 
Aliás, no que tange ao âmbito material eles divergem. Assim, os Princípios UNIDROIT restringem-se aos contratos comerciais e internacionais $^{367}$ já, por sua vez, os PECL aplicam-se a todos os tipos de contrato, incluindo as transações de carácter puramente doméstico. Ao nível territorial, enquanto os Princípios UNIDROIT são, tendencialmente, universais, os PECL limitam-se aos Estados-Membros da UE, ainda que não existam impedimentos que impeçam Estados extra UE de recorrer a eles. Aliás, excecionando as relações com os consumidores, é cada vez mais difícil falar de um direito contratual especificamente europeu ${ }^{368} 369$.

A título comparativo, muitos são os artigos constitutivos dos Princípios UNIDROIT que têm critérios correspondentes nos PECL ${ }^{370}$.

Os princípios base convergentes nestes dois instrumentos são: a liberdade contratual [art.1.1 UNIDROIT; art.1:102 Princípios Lando]; liberdade de forma [art. 1.2 UNIDROIT; art. 2:101. (2) Princípios Lando]; pacta Sunt Servanda [art. 1.3 UNIDROIT; art. 1:201 Princípios Lando]; bona-fides [art. 1.7 UNIDROIT; art. 1:201 Princípios Lando]; finalmente, os usos e costumes como fontes para a formação, para o cumprimento e extinção dos contratos internacionais [art. 1.9 UNIDROIT; 1:105. Princípios Lando].

Há, também, divergências, quer de natureza técnica, ${ }^{371}$ que corresponde à maior parte, quer, ainda, de natureza política ${ }^{372}$ e matérias que constam apenas em uns e não em outros.

- The UNIDROIT Principles of International Commercial Contracts and the Principles of European Contract Law: Similar Rules for the Same Purposes?, 26 Uniform Law Review (1996), págs. 229 (246).

367 Vide comentário ao Preâmbulo dos princípios UNIDROIT [3]. Assim, ainda que tenham sido concebidos para os contratos mercantis internacionais, não existe nenhum impedimento para que os particulares possam aplica-los a contratos estritamente internos ou nacionais. "No entanto, o acordo estará "sujeito às normas imperativas do país cujo ordenamento jurídico seja aplicável ao contrato."

${ }^{368}$ Sobre o carácter progressivo dos PECL. In Lando / Beale, ob cit. xvi

${ }^{369}$ Gostaríamos de mencionar, todavia, que estes princípios poderão servir de base a um futuro código europeu dos contratos e para a edificação de uma verdadeira "infraestrutura" para a legislação, em matéria contratual, da União Europeia. In ibidem., xvi e ss.Aliás, o reflexo dessa evolução está na criação de uma Quadro Europeu Comum de Referência em matéria de contratos (QFR).

370 Pelo menos 70, tendo em linha conta as limitações da análise feita pela autora. In PEREIRA, Teresa Silva - Proposta de reflexão sobre um Código Civil Europeu, $o b$. cit.. 
Decorre do preâmbulo dos Princípios UNIDROIT, no seu 3. ${ }^{\circ}$ parágrafo, que o contrato transnacional, se as partes acordarem, poderá ser "regulado pelos princípios gerais de direito, pela lex mercatoria, ou similares. ${ }^{373 "}$ O mesmo se passa com os Princípios do Direito Europeu dos Contratos (PECL). Podendo ser aplicados quando as partes aceitam que o contrato seja regimentado pelos princípios gerais de Direito, lex

371 Ilustramos alguns dos exemplos: os Princípios UNIDROIT acolheram a teoria da receção para quaisquer notificações existentes entre as partes [art. 1.9 (2)], já os PECL adotaram a teoria do envio a operar nos casos de notificação que tenha como origem o incumprimento [art. 1:303 (4)]; os Princípios UNIDROIT para os casos de o terceiro não poder ou não querer proceder à fixação do preço, este deverá ser razoável [art. 5.7 (3)], os PECL consideram sob presunção que as partes atribuem competência ao tribunal no sentido de que este proceda à nomeação de uma outra pessoa que o irá determinar [art. 6:106 (1)]; os Princípios UNIDROIT, no caso de impossibilidade total e permanente [absoluta] dispõem que a cessação do contrato dependerá da iniciativa das partes [art. 7.1 .7 (4)], já, os PECL estatuem a cessação automática [art. 9:303 (4)]; Vide nota 56 In PEREIRA, Teresa Silva - Proposta de reflexão sobre um Código Civil Europeu, $o b$. cit..

372 "As diferenças de natureza política dependem do facto dos corpos de princípios terem âmbitos de aplicação diferentes. Assim, por se aplicarem apenas a contratos comerciais, os Princípios UNIDROIT referem-se ao dever de actuar conforme à boa fé e ao "fair dealing" no comércio internacional (art. 1.7), enquanto nos PECL este dever é citado em termos gerais (art. 1:201); também quanto aos usos, se referem os Princípios UNIDROIT aos amplamente conhecidos e regularmente observados no comércio internacional pelas partes envolvidas num determinado tipo de comércio (art. 1.8(2)). Já os PECL consideram que as partes estão vinculadas pelos usos geralmente aplicáveis por pessoas na mesma situação das partes (1:105 (2)). Existem diferenças que decorrem do facto dos Princípios UNIDROIT se aplicarem apenas a contratos entre comerciantes ou outros profissionais. Os PECL, por exemplo, limitam algumas disposições a situações em que as partes sejam profissionais e prevêem a hipótese de eliminação de cláusulas contratuais não negociadas individualmente por serem injustas e afectarem o equilíbrio entre as partes (art. 4:110). Um outro tipo de diferenças resulta do âmbito internacional dos Princípios UNIDROIT. Assim, no tocante aos modos de pagamento, os PECL estipulam que uma obrigação monetária expressa numa unidade monetária diferente daquela em vigor no lugar do pagamento pode sempre ser paga na unidade monetária do lugar do pagamento à taxa de câmbio corrente, a não ser que as partes tenham estipulado que o pagamento apenas pode ser feito na unidade monetária acordada (art. 7:108 (1)(2)) e os Princípios UNIDROIT acrescentam ainda o caso da unidade monetária do lugar de pagamento não se poder converter livremente (art. 6.1.9(1)(a)), por ser esta ainda a situação em alguns países." Vide nota 57 in , PEREIRA, Teresa Silva - Proposta de reflexão sobre um Código Civil Europeu, ob. cit. .

${ }^{373}$ Princípios UNIDROIT relativos aos contratos comerciais internacionais 2010. Translation by Professor Lauro Gama, Jr. (Professor of Law, Catholic University of Rio de Janeiro PUC-RIO; Senior Partner, Binenbojm, Gama \& Carvalho Britto Advogados; Member of the Working Group for the preparation of the UNIDROIT Principles of International Commercial Contracts). 
mercatória ou fórmula similar, ou mesmo quando as partes não escolham o sistema ou as regras disciplinadoras do mesmo contrato. (art. ${ }^{\circ} 1: 101$ (2) e (3) $)^{374}$.

A propósito, quando as partes tenham feito referência à lex mercatoria ou a uma fórmula semelhante, a aplicação, seja dos princípios UNIDROIT, seja dos princípios LANDO, depende da interpretação feita à cláusula de electo iuris ${ }^{375}$. Desta feita, é espectável que um operador [médio] do comércio transnacional considere tanto as práticas, usos e costumes do comércio transnacional, as regras elaboradas pelas diversas organizações profissionais [em destaque, aquelas no setor específico de ação do contrato] $]^{376}$.

Conforme já fora abordado para os Princípios UNIDROIT, estes princípios partilham com os PECL de algumas características que para Godé, traduzem o seu sucesso. $\mathrm{O}$ fato de nenhum dos instrumentos ter caráter obrigatório - tendo natureza jurídica de Soft Law - de não terem sofrido a influência pelos diversos governos e de não constituírem qualquer ameaça para as ordens jurídicas estaduais ${ }^{377}$.

Os Princípios Lando foram criados por juristas de renome dos diversos países europeus, sob a presidência do professor dinamarquês Ole Lando motivo pelo qual são também denominados Princípios Lando.

Um dos objetivos essenciais que presidiu à sua elaboração foi para além sublinhar os princípios já existentes na prática mercantil internacional, estabelecer um conjunto de critérios jurídicos com a finalidade de reduzir ou, mesmo eliminar, as diferenças existentes entre os ordenamentos jurídicos nacionais, potenciando o desenvolvimento do comércio na Europa, operando como resposta à globalização dos mercados.

O projeto inicial dos princípios Lando surgiu em 1980. A primeira comissão (Lando) reuniu-se de 1980 até 1990, período durante o

\footnotetext{
${ }^{374}$ Vide No caso de lacunas do sistema ou das regras utilizadas, a possibilidade integrativa dos Princípios no art. 1.101 (4). Convém atentar que prefiguramos esta hipótese, por forma mais segura, em sede arbitral, atentando ao distanciamento, pelo menos a título de direito substantivo, da lei nacional.

375 Vide CANARIS, Claus-Wihlelm, - Stellund der "UNIDROIT"Principles, und der Principles of European Contract Law, pág. 27.

${ }^{376}$ Vide art. 1.9 dos Princípios UNIDROIT

377 GOODE, Roy - Communication on European Contract Law (reação à Comunicação da Comissão). Disponível em: http://europa.eu.int/comm/consumers/consint/ /safe-shop/fair-bus-pract/cont-law/comments/academics/index-en.htm, pág. 5. Consultado em: 19-02-2015
} 
qual foram discutidas as bases para a elaboração dos princípios. Esses princípios foram adotados pela supra indicada Comissão em 1990. Todavia, somente uma segunda comissão, entre 1992 até 1996, termina a redação das Partes I e II dos Princípios. Na data de 1995, fora publicada a Parte I onde contam os Princípios relativos à execução, inexecução e meios de defesa [remedies]. Em 1999, foram publicadas a Parte I, revista, e a Parte II, que abarca a formação do contrato, a representação, a validade, interpretação, conteúdo, execução, inexecução e meios de defesa [remedies]. De 1997 até 2001, foram realizadas mais reuniões, estas tendo como objetivo redigira terceira parte dos Princípios Lando que irá complementar as partes I e II. Em 2003, foi publicada a Parte III relativa à pluralidade de partes, cessão de créditos, transmissão da posição contratual, compensação, prescrição, ilegalidade, condições e capitalização de juros $^{378}$.

Consideramos, no que respeita à posição assumida quanto à natureza dos Princípios UNIDROIT, o mesmo entendimento, embora com as necessárias adaptações, tendo em conta as limitações geopolíticas evidentes, para os Princípios LANDO. Aliás, tantos são mais os elementos que os unem que os elementos que os separam ${ }^{379} 380$.

Finalmente, no plano da presente seção das fontes, e no sentido do que vem sido afirmado, fechamos com a não menos importante Convenção Interamericana sobre o Direito Aplicável aos Contratos Internacionais de 1994 quando, nos seus artigos, 3. ${ }^{\circ}, 9^{\circ}$ e $10 .^{\circ}$, faz menção às fontes da new law merchant ${ }^{381}$.

\footnotetext{
378 Vide LIMA PINHEIRO, - Direito Comercial Internacional, pág. 193.

379 Basta atentarmos ao princípio da autonomia da vontade, a importância reconhecida à certeza e segurança jurídicas e à justiça.

380 Segundo Lando os PECL, nas transações realizadas, pelo menos, entre uma parte extra UE poderiam ser aplicados como lex mercatoria. Vide LANDO, O. - The Principles of
} European Contract Law and the lex mercatoria, pág. 391 (397).

381 Vide.

Artigo 3

As normas desta Convenção serão aplicáveis, com as adaptações necessárias e possíveis, às novas modalidades de contratação utilizadas em consequência do desenvolvimento comercial internacional;

\section{Artigo 9}

(...)O tribunal levará em consideração todos os elementos objetivos e subjetivos que se depreendam do contrato, para determinar o direito do Estado com o qual mantém os vínculos mais estreitos. Levar-se-ão também em conta os princípios gerais do direito comercial internacional aceites por organismos internacionais. (...) 
A criação dos princípios de UNIDROIT e dos outros instrumentos mencionados produziram um frutuoso impacto sobre as principais críticas lançadas à nova lex mercatoria, de entre as quais cumpre destacar: a fragmentariedade ou, mais precisamente, a setorização, a heterogeneidade e a incompletude regulativa. De fato, estas constituem caraterísticas fundamentais para a existência e continuidade de um sistema dinâmico e autossuficiente.

Posicionando-se como uma alternativa de caráter material à disciplina regulativa dos direitos nacionais e ao direito de conflitos, podendo, desta feita, aplicar-se a qualquer contrato transnacional. Pelo que, poderá funcionar como lex contractus através de um pacto de lege utenda e até, mesmo, na sua ausência, tornar-se, efetivamente, a disciplina do respetivo contrato ${ }^{382}$.

Constatando a importância destes instrumentos, alguns autores, consideram que, a par dos princípios gerais de direito, devemos incluir, também, as regras comuns aos diferentes sistemas jurídicos nacionais, enquanto fórmulas de resolução dos litígios emergentes das questões privadas transnacionais, típicas da new law merchant ${ }^{383}$.

Atentando à natureza jurídica destes princípios (soft law ou direito flexível), incluiremos, ainda, como fonte da nova lex mercatoria, uma outra componente constitutiva do Direito Internacional Público. Reportamo-nos, entre outras, às resoluções, aos pareceres, às diretivas, (gui-

\section{Artigo 10}

Além do disposto nos artigos anteriores, aplicar-se-ão, quando pertinente, as normas, costumes e princípios do direito comercial internacional, bem como os usos e práticas comerciais de aceitação geral, com a finalidade de assegurar as exigências impostas pela justiça e a equidade na solução do caso concreto. Sublinhado e negrito nossos.

382 Vide CASTELLANOS RUIZ, E. - Autonomia conflictual y contratos internacionais: Algunas reflexiones, Cuestiones actuales de Derecho Mercantil Internacional. CALVO CARAVACA, Alfonso Luis; AREAL LUDEÑA, Santiago (Dirs). Madrid, 2005, Colex, págs. 459 e ss.

${ }^{383}$ Entre outros autores, Vide GOLDMAN, B. - La lex mercatoria, ob. cit. págs. 485 487; FOUCHARD, Ph, - L'État face, ob. cit. págs. 73 - 74; GOLDSTAJN, A., - Usages of Trade, ob. cit. pág. 72; PRAENDL, F. - Measures od Damages in International Commercial Arbitration, in SJIL, 1987, pág. 276; LOQUIN, E. - L'amiable, ob. cit. pág. 311; HOFFMANN, B. Von - Grundsätzliches zur Anwendung der «lex mercatoria» durch internationale Schiedsgerichte, in Festschrift fur Gerhard Kegel zum 75. Geburtstag 26. Juni 1987, Estugarda/Berlin/Colónia/ Mogúncia, W. Kohlhamer, 1987. 215-233, págs 220 e ss; LANDO, O. - The Lex Mercatoria, ob. cit. pág. 749. 
delines, directives), aos guias profissionais, às recomendações, aos códigos de conduta ou de comportamento ${ }^{384}$, aos códigos de deontologia, etc $^{385}$.

Consideramos, ainda, pertinente salientar a ordem pública transnacional ou verdadeiramente internacional enquanto concretização funcional da heterointegração negativa (do sistema normativo global).

384 A lex mercatoria, também teria por base outros elementos, como o próprio Direito Internacional Público, leis uniformes e regras de organizações internacionais [como resoluções, recomendações, códigos de conduta no âmbito do comercio internacional]. LAKE, Ralph B. -Breach and adaptation of international contracts: an introduction to lex mercatoria. Salem, Butterworth Legal Publishers, 1992, pág. 13. Vide também, LANDO, O. - The Lex Mercatoria, $o b$. cit. págs. 748-751, onde elenca os seguintes elementos: o Direito internacional público, o Direito uniforme, os princípios gerais de direito, as regras de organizações internacionais, os usos e costumes, os modelos contratuais standard; os relatórios das sentenças arbitrais; sobre os códigos de conduta Vide, também, RIGAUX, F. - Pour una utre orde international, in BLANC, J. - RIGAUX F., - Droit Économique II, Paris, Pedone, 1979, págs. 364-399, e MARQUES DOS SANTOS, A. - Transferência internacional de tecnologia, economia e direito - alguns problemas gerais, Lisboa, Centro de Estudos Fiscais, 1984 (Cadernos de Ciência e Técnica Fiscal, n. ${ }^{\circ}$ 132), págs 309 e ss.. Mostra pormenores acerca da elaboração pela Conferência das Nações Unidas sobre o Comércio e o Desenvolvimento - UNCTAD- dos Códigos de conduta em Matéria de Transferência de Tecnologia e sobre Empresas Multinacionais. Vide GOLDSTAJN, A. - Usages of Trade, ob. cit. pág. 72; SIEHR, K. , Sachrecht im IPR, transnationales Recht und lex mercatoria. in HOLL, W. - KLINKE U., - Internationales Privatrecht - Internationales Wirtschaftsrecht, Colónia/Berlim/Bona/Mogúncia, Carl Heymanns Verlag, 1985, pág. 114. Inclui os tratados internacionais, as diretivas uniformes, também, os formulários e as cláusulas sobre o comércio marítimo, os contratos-standard e as condições gerais das Câmaras de Comércio existentes nos Estados e dos diversos agrupamentos comerciais, a jurisprudência arbitral e a dos tribunais estaduais, as práticas ou usos do comércio internacional, isto, para além dos códigos de conduta ou de comportamento. Sobre estes, Vide ainda. HORN, N. - Die Entwicklung des Internationalen Wirtschaftsrechts durch Verhaltensrichtlinien - Neue Elemente eines internationalen ordre public, Rabelsz, 1974, págs. 423 e ss. Negrito nosso.

385 Sobre o Direito flexível, FERNÁNDEZ ROZAS, J. C. - Derecho del comercio internacional, Madrid, EUROLEX, 1996, págs. 47-48; também MARQUES DOS SANTOS, A. - Transferência internacional de tecnologia, economia e direito - alguns problemas gerais, Lisboa, Centro de Estudos Fiscais, 1984, págs. 288-319. CARLOS SANTOS, A. GONÇALVES M. Eduarda, LEITÃO MARQUES, M. Manuel - Direito Económico, Coimbra, Almedina, 1993, págs. 356-357. 


\section{UMA NOTA SOBRE O DIREITO HARMONIZADO, UNIFICADO E UNIFORME E REGRAS DE ORGANIZAÇÕES INTERNACIONAIS, COMO FONTE DA NOVA LEX MERCATORIA}

Não poderemos deixar de atender ao direito harmonizado, unificado e uniforme e a determinadas regras de organizações internacionais. Também, por maioria de razão, fontes da nova lex mercatoria ${ }^{386}$.Falamos da Convenção da CNUDCI ou UNCITRAL sobre a compra e venda internacional (1980), sigla CISG ${ }^{387}{ }^{388}{ }^{389}$; das Convenções de Haia sobre contratos internacionais criadas pela Conferência de Haia de Direito Internacional Privado, onde se promoveu a adoção do princípio da autonomia da vontade. Convenções sobre a lei aplicável à venda de bens móveis (1955); sobre a transferência da propriedade (1958); sobre a lei aplicável aos contratos de intermediários e representação (1978); sobre a lei aplicável aos contratos de venda internacional de mercadorias (1986). Ainda a Convenção das Nações Unidas sobre Letras de Câmbio Internacionais e de Notas Promissórias Internacionais de 1988, aberto à assinatura e ratificação desde a mesma data. A Convenção das Nações Unidas sobre o Uso

\footnotetext{
${ }^{386}$ Lando quando faz coincidir a aplicação da lex mercatoria com todos os caso em que os árbitros aplicam normas anacionais ao mérito da causa. LANDO, O, - The Lex Mercatoria, ob cit. pág. 747. O autor elenca como fontes da nova lex mercatoria, entre outras, as convenções internacionais com regras uniformes sobre compra e venda internacional, regras de Direito internacional público sobre os tratados (Convenção de Viena de 1969),tendo por base o facto de terem, já, sido aplicadas, como forma de regulamentação, a contratos celebrados entre Estados e nacionais de outros Estados. In ibidem., pág. 749. Incluindo, também, no elenco das fontes da lex mercatoria, as Convenções internacionais, tendo em consideração argumentos análogos a este autor. Vide HOFFMANN, B. Von Grundsätzliches zur Anwendung der «lex mercatoria» durch , ob. cit. pág. 220. 387 Vide UNCITRAL - "Nota explicativa da secretaria da UNCITRAL sobre a Convenção das Nações Unidas sobre contratos de compra e venda internacional de mercadorias." Disponível em: http://www.cisgbrasil.net/doc/explnotecisgtradamadeusorleans-final.pdf . Consultado em: 21-02-2015 ${ }^{388}$ A sua redação foi construída sob a inspiração de modelos já utilizados na prática mercantil das diversas sociedades, em especial a lex mercatoria, que terá contribuído, profundamente, para a elaboração de uma lei uniforme. Vide KHAN Ph. - Les príncipes généraux du droit devant les arbitres du commerce international. JDI, 1989, pág. 305. Segundo este autor, o comércio internacional cria as suas regras, que paulatinamente vão sendo integradas ao direito comercial positivo. As regras de conduta das partes têm por base, maioritariamente, os usos mercantis (mencionados, também, nas decisões arbitrais). ${ }^{389}$ A par da lex mercatoria, terão influenciado: o BGB alemão e o Uniform Commercial Code americano.
} 
das Comunicações Eletrônicas nos Contratos Internacionais, da UNCITRAL (2005), a Convenção Internacional sobre contratos de viajem, de Bruxelas (1970), a Convenção sobre agência na venda internacional de bens, de Genebra (1983), a Convenção UNIDROIT sobre factoring internacional, de Ottawa (1988), a Convenção UNIDROIT sobre objetos culturais roubados ou exportados ilegalmente de Roma (1995), a Lei-Modelo da Arbitragem, da UNCITRAL (2002, com as alterações introduzidas em 2006), a lei-modelo (CCI) da compra e venda internacional, publicação n. ${ }^{\circ} 556$ (1997), a lei-modelo sobre transferência de créditos internacionais, de 1992, a lei-modelo sobre comércio eletrônico de 1996, Leimodelo sobre assinaturas eletrônicas de 2002, as cláusulas de força maior CCI (2003) e as cláusulas de Hardship CCI (2003) n. ${ }^{\circ}$ 650, 2003, em especial, no âmbito das operações bancárias, a Convenção sobre garantias independentes e cartas de crédito stand-by (CGI) (1995) e a Lei- Modelo sobre os aspetos legais relacionados com o Intercambio Eletrónico de Dados (IED) (1994), a Lei Modelo de Franchising UNIDROIT, de Roma (2002), a Lei Modelo de Leasing UNIDROIT, de Roma, 2008.

Consideramos, também, a Lei Uniforme sobre letras e livranças, de acordo com as Convenções de Genebra, de 1930 e, também, sobre cheques de 1931.

\section{CONSIDERAÇÕES FINAIS}

Entendemos que a amplitude da realidade jurídica denominada de nova lex mercatoria em nada prejudica o destaque, nas suas fontes, dos usos e costumes criados pelos operadores do comércio internacional, em detrimento de todas as outras.

Não obstante, uma visão distinta sobre a atual configuração da realidade a estudo nos convoca.

Incontestavelmente, a new law merchant não mais representa aquele corpo normativo constituído, apenas, por usos e costumes do comércio jurídico transnacional, nascido da Idade Média.

Ela não embrutecera, antes desenvolvera, por diversas vias, estratégias de adaptação ao mundo globalizado. Por outro lado, fora interpenetrada por diversos fatores externos florescendo a sua anterior natureza e, simultaneamente, fortalecendo a sua estrutura. 
Entendemos que a nova lex mercatoria é formada não só pelos usos e costumes do comércio internacional. Deveremos ter em consideração o caráter evolutivo deste último. O lançar mão a outras realidades, v.g princípios gerais de direito, princípios e regras codificadas por organizações internacionais entre outros organismos, não mais é que admitir desenvolvimentos das valorações axiológicas provindas do direito natural, ora, mesmo positivadas, mas que se assumem como critérios orientadores e mesmo disciplinadores das relações entre os operadores do comércio internacional. A eficiência deste sistema "operativo" reclama justificações equitativas.

A par do descrito, urge lembrar que a realidade que, ora, nos ocupa constitui uma feliz manifestação, no comércio jurídico transnacional, da nova ordem global, proveniente dos efeitos, voluntários e involuntários, da globalização e mundialização e do consequente pluralismo unitário jurídico-valorativo, que, ora, caraterizam o espírito do sistema da nova lei dos mercadores.

\section{REFERÊNCIAS BIBLIOGRÁFICAS}

AIDAN, P. - Droit des marchés financiers. Reflexión sur les sources. La Revue Banque, 2001;

ANTUNES VARELA, João de Matos, - Das Obrigações em Geral, Vol. I, 10. ${ }^{2}$ Edição, Coimbra, Almedina, 2000;

ANTUNES, J. Engrácia, A. - Direito dos Contratos Comerciais, Coimbra: Almedina, 2009 - "Consueto Mercatorum" como Fonte do Direito Comercial, in: 146 RDMIEF (2007), 7-22;

ASCENSÃO, JOSÉ DE OLIVEIRA, - Teoria Geral do Direito Civil. Volume III. Acções e Factos Jurídicos, Lisboa, s. ed., 1991/1992;

BAPTISTA MACHADO, J. - Introdução ao direito e ao discurso legitimador, Coimbra: Almedina, 1990;

BAPTISTA, Luiz Olavo, - Les Joint ventures dans les relations internationales, Doutoramento, Paris, 1981 ;

BARBOSA RODRIGUES, LUÍS, - Manual de Introdução ao Direito: Interno e Internacional, FORMALPRESS, 2011;

BERGER, K., P. - The Relationship between the UNIDROIT Principles of International Commercial Contracts and the New Lex Mercatoria, Uniform Law Review, 2000-1; 
BERGER, Klaus Peter - Formalisierte oder "schleichende" Kodifizierung des transnationalen Wirtschaftsrecht, Berlim e Nova Iorque, 1996; - The Creeping Codification of the Lex Mercatoria, A Haia, Londres e Boston, 1999; -The Lex Mercatoria Doctrine and the UNIDROIT Principles of International Commercial Contracts. In: Law and Policy in International Business. 1997;

BONELL, M. J. - The New Edition of the Principles of International Commercial Contracts adopted by the International Institute for the Unification of Private Law, Uniform Law R. 9: 5-40. 2004; - The New Edition of the Principles of International Commercial Contracts adopted by the International Institute for the Unification of Private Law, Uniform Law R. 9: 5-40. 2004 ; - The UNIDROIT Initiative for the Progressive Codification of International Trade Law, The International and Comparative Law Quarterly, 1978; -The UNIDROIT Principles of International Commercial Contracts and the Principles of European Contract Law: Similar Rules for the Same Purposes?, 26 Uniform Law Review, 1996;

BYRNE, J. - The Comparison Between UCP500 and UCP600, Institute of Banking Law and Practice, Montgomery, 2007 ;

CALVO CARAVACA, A. L.; CARRASCOSA GONZÁlEZ, J. - Curso de Contratación Internacional. Madrid, Editorial Colex, 2003;

CALVO CARAVACA, A.L.; CARRASCOSA GONZÁLEZ, J, E OUTROS - Derecho internacional privado, Vol.II, Granada, Comares, 2000;

CANARIS, Claus-Wihlelm - Stellund der "UNIDROIT" Principles, und der Principles of European Contract Law ;

CARDOSO RODRIGUES, Ricardo Alexandre - O Contrato de Engineering: Algumas Reflexões (The Engineering Contract: Some Reflection), Setembro de 2014; - Regulação apositiva da contratação internacional - New law merchant, Dissertação de Mestrado, Repositório FDULP, 2012;

CARLOS SANTOS, A. GONÇALVES M. Eduarda, LEITÃO MARQUES, M. Manuel - Direito Económico, Coimbra, Almedina, 1993;

CASTELLANOS RUIZ, E. - Autonomia conflictual y contratos internacionais: Algunas reflexiones, Cuestiones actuales de Derecho Mercantil Internacional. CALVO CARAVACA, Alfonso Luis; AREAL LUDEÑA, Santiago (Dirs). Madrid, Colex, 2005; 
CASTRO MENDES, J. - Introdução ao estudo do direito, 3. ${ }^{\mathrm{a}} \mathrm{Ed}$. Lisboa, 2010;

CRAIG; PARK; PAULSSON - International Chamber of Commerce arbitration, Oceana Publications, 2000 ; - Annotated Guide to the 1998 ICC Arbitration Rules, Oceana Publications, 1998;

DAVID, R. - L'arbitrage dans le commerce international, Paris, Económica. 1982; - Le droit du commerce international : une nouvelle tâche pour les législateurs nationaux ou une nouvelle «lex mercatoria »?, in New Directions in International Trade Law, vol. I(reports), Nova Iorque, Oceana Publications, 1977 ; - Arbitrage et Droit compare, in RIDC, 1959 ;

DERAINS, Y. - Les normes d'application immédiate dans la jurisprudence arbitrale, in Le droit des relations économiques internationales - Études offertes à Berthold Goldman, Paris, Librairies Techniques, 1983 ;

DIAS MARQUES, J. - Introdução ao Estudo do Direito, 4. a ed., Lisboa, 1972;

DRAETTA, Ugo, - Gli Usi del Commercio Internazionale nella Formazione di Contratti Internazionali, in: DRAETTA, Ugo/ VACCÀ, Cesare (dir.), "Fonti e Tipi del Contratto Internazionale", Milão, EGEA, 1991.

DURÁ, R. Marimón - La Nueva Editión de las Reglas de la CCI para los Créditos Documentários, in: 263 RDM, 2007;

E. LOQUIN/ L.RAVILLON. : "La creation d'un espace juridique mondial. La volonte des operateus vecteurs d'un droit mondialise", La Mondialisation du Droit. E. LOQUIN e C. KESSEDJIAN (dirs), Dijon Litec, - CREDIMI, 2000;

EBERTH, Rolf - Zur Rechtnatur der Einheitlichen Richtlinien un Gebräuche für Dokumentenakkreditive, in : "Festschrift für Karl-H. Neumayer", Nomos, Baden-Baden, 1986 ;

EISEMANN, F. - Usages de la vente commerciale internationale Incoterms: aujourd'hui et demain, Paris : Editions Jupiter, 1980 ;

ELLSCHEEID, - O problema do direito natural. Uma orientação sistemática, in KAUFMANN/HASSEMER (Eds), - Introdução à Filosofia do Direito e à Teoria do Direito Contemporâneas (trad. port.), Lisboa, 2002;

FERNANDES, Luís A. Carvalho, - Teoria Geral do Direito Civil -Vol.

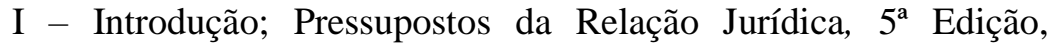
Universidade Católica, 2009; 
FERNÁNDEZ ROZAS, J. C. - Derecho del comercio internacional, Madrid, EUROLEX, 1996; - Ius mercatorum. Autoregulación y unificación del derecho de los negócios transnacionales. Colegios Notariales de España, Madrid, 2003;

FERRARESE, $M^{a}$. R. - La lex mercatoria tra storia e attualità: da diritto dei mercanti a lex per tutti? , Sociologia del Diritto, Milan, 2005;

FERREIRA DE ALMEIDA, C. - Meios jurídicos de resolução de conflitos económicos, Boletim da Faculdade de Direito de Bissau, n. ${ }^{2}$, Setembro de 1993;

FERRER CORREIA - "Da arbitragem comercial internacional", in Temas de Direito Comercial. Arbitragem Comercial Internacional. Reconhecimento de Sentenças Estrangeiras. Conflitos de Leis, Coimbra, 1989

FOUCHARD, Ph, - L'arbitrage comercial international, Paris, Dalloz, 1965 ; - L'Etat face aux usages du commerce international, in TCFDIP 1973/1975, Paris, Dalloz, 1977 ; - L'arbitrage commercial international, Paris, Dalloz, 1965 ; - Les usages, l'arbitre et le juge, in Le droit des relations économiques internationales - Études offertes à Berthold Goldman. Paris, Librairies Techniques, 1983.

FRIGNANI, A. - Il contrato internazzionale, Trattato di diritto commerciale e di diritto pubblico dell'economia diretto da Francesco Galgano, vol. XII, Padova, 1990;

GALGANO, F. - La globalización en el espejo del Derecho, Rubinzal, Buenos Aires, 2005; - La globalizzazione nello specchio del diritto, Bologna, Il Moulino. 2005. Tradução espanhola por Roitman, H. y De La Colina, $\mathrm{M}^{\mathrm{a}}$. . - La globalización en el espejo del Derecho, Santa Fe, Rubinzal-Culzoni. 2005;

GALVÃO TELLES, - Introdução ao Estudo do Direito, Vol. I, Coimbra: Coimbra Editora, 2010; - Direito das obrigações. 6. ${ }^{a}$ Edição, Almedina, 1989 ; - Manual dos Contratos em Geral. 3. ${ }^{a}$ edição, Lisboa, Petrony, 1965;

GARCEZ, José Maria Rossani. - Negociação, ADRs, Mediação e Arbitragem. Rio de Janeiro, Ed. Lúmen Júris, 2003 ;

GOLDMAN B., - La lex mercatoria dans les contrats et l'arbitrage international: realité et perspectives, Clunet Vol. $106:$ 475-505, 1979 ; - Frontières du droit et «lex mercatoria», in Archives de philosophie du droit, n. ${ }^{\circ} 9$ - Le droit subjectif en question, Paris, Sirey, 1964.; 
GOLDSTAJN A. - International conventions and standard contracts as means of escaping from the application of municipal law -1 . The sources of the law of international trade with special reference to East-West Trade., Schmitthoff, C. M. ed., London, Stevens \& Sons, 1964; - Usages of trade and other autonomous rules of international trade according to the UN (1980) sales convention. In International sale of goods; Dubrovnik lectures. Sarcevic, P. and P. Volken, eds. New York, Oceana, 1986 ;

GONÇALVES PEREIRA, A.; QUADROS, Fausto de, - Manual de Direito Internacional Público, 3. ${ }^{a}$ edição, Coimbra: Almedina, 1993;

GOODE, Roy - Commercial Law, Penguin, Middlesex / New York, 1982 ;

GOTTWALD, Peter, - Internationale Schiedsgerichtsbarkeit. in Internationale Schiedsgerichtsbarkeit, org., por Peter GOTTWALD (CIT.) 3-160, 1997 ;

HERNÁNDEZ RODRÍGUEZ, A.- Los Contratos internacionales de construcción "Ilave en mano", Granada, Comares, 1999;

HESPANHA, António Manuel, - Cultura Jurídica Europeia, Síntese de um milénio, Coimbra, Almedina, 2015;

HOFFMANN, B. Von - Grundsätzliches zur Anwendung der «lex mercatoria» durch internationale Schiedsgerichte, in Festschrift fur Gerhard Kegel zum 75. Geburtstag 26. Juni 1987, Estugarda/Berlin/Colónia/ Mogúncia, W. Kohlhamer, 1987;

HORN, N. - Die Entwicklung des Internationalen Wirtschaftsrechts durch Verhaltensrichtlinien - Neue Elemente eines internationalen ordre public, Rabelsz, 1974;

HORSMANS, Guy. - L'interprétation des contrats internationaux, in L'apport de la jurisprudence arbitrale: Séminaire des 7 et 8 avril 1986 (ICC Publishing S.A.), 1986 ;

KAHN $\mathrm{Ph}$. - Force majeure et contrats internationaux de longue durée, in Jus et Societas - Essays in Tribute to Wolfgang Friedmann, Haia/Boston/Londres, Martinus Nijhoff, 1979 ; -'Lex mercatoria' et pratique des contrats internationaux : l'expérience française, in Le contrat économique international - stabilité et évolution, Travaux des VII es Journées d'études juridiques Jean Dabin, Bruxelas/Paris, Bruylant/Pedone, 1975; - La vente commerciale internationale, Paris, Sirey, 1961; - Lex mercatoria et euro-obligations, in Law and Înternational Trade - Festschrift fur Clive M. Sch- 
mitthoff, Frankfurt a. M., Athenaum Verlag, 1973; L'interprétation des contrats internationaux, CLUNET, 1981; - Les príncipes généraux du droit devant les arbitres du commerce international. JDI, 1989 ;

KASSIS, A. - Thèorie genèrale des usages de commerce, LGDJ, Paris, 1984 ;

KELSEN, Hans. - Teoria geral do direito e do estado. 3. ed. Tradução de Luís Carlos Borges, São Paulo: Martins Fontes, 1998;

LAKE, Ralph B. -Breach and adaptation of international contracts: an introduction to lex mercatoria. Salem: Butterworth Legal Publishers, 1992;

LALIVE, P. - Les règles de conflit de lois appliquées au fond du litige par l'arbitre international siégeant en Suisse, in L'arbitrage international privé et la Suisse, Colloque des 2 et 3 avril 1976, Genebra, Georg- Librairie de l'Université, 1977 ;

LANDO, O. - The Principles of European Contract Law and the lex mercatoria, in Private Law in the International Arena. Liber Amicorum Kurt Siehr, 391-404, A Haia, 2000; - Principles of European Contract Law. Parts I \& II Combined and Revised, Dordrecht, Boston e Londres, 2000; - Lex mercatoria 1985-1996, in Festskrift til Stig Strömholm, V. II, 567-584, Uppsala, 1997; Principles of European Contract Law. An Alternative or a Precursor of European Legislation, Rabels Z. 56: 261-273. 1992;- The lex mercatoria in International Commercial Arbitration, in International Comparative Law Quarterly ICLQ, 1985;

LANDO,O. / BEALE, Hugh, - The Principles of European Contract Law, Dordrecht, Boston e Londres, 1995;

LARENZ, Karl/ CANARIS, Claus-Wilhelm, - Methodenlehre der rechtswissenschaft, 3 . $^{\text {a }}$ edição, Berlim et al., 1995;

LIMA PINHEIRO, Contratos de Empreendimento Comum (Join Venture) em Direito Internacional Privado, Lisboa, Almedina., 1998; - Direito Comercial Internacional, Coimbra, Almedina, 2005 ;

LOQUIN E. - L'amiable composition en droit comparé et international - Contribution à l'étude du non-droit dans l'arbitrage commercial, Paris, Librairies Techniques, 1980 ;

LOUSSOUARN, Yvon ; BREDIN, Jean-Denis, - Droit du commerce international. Paris, Sirey,1969; 
MARMOL, Ch. Del, - Les clauses contractuelles types, facteur d'unification du droit commercial, in Liber Amicorum Baron Louis Frédéricq, Vol. 1, Gand, Faculteit der Rechtsgeleerdheid te Gent, 1965 ;

MARQUES DOS SANTOS, A. - Transferência internacional de tecnologia, economia e direito - alguns problemas gerais, Lisboa, Centro de Estudos Fiscais, 1984 (Cadernos de Ciência e Técnica Fiscal, n. ${ }^{\circ}$ 132);

MARTINEZ CAÑELLAS. A. - La interpretación y la integración de la Convención de Viena sobre la compraventa internacional de mercaderías de 11 de abril de 1980, Granada, Ed. Comares, 2004; - Temas de Derecho Vivo, Madrid: Civitas, 1978;

MAYER, P. - Droit international privé et droit international public sous l'angle de la notion de compétence, $R$. critique ;

McDOWELL, Carl; GIBBIS, Helen - Ocean Transportation. Washington: Beard Books, 1999;

MEHREN, A.T. Von, - To What Extent is International Commercial Arbitration Autonomous?, in Le droit des relations économiques internationales - Études offertes à Berthold Goldman, Paris, Librairies Techniques, 1983 ;

MENEZES CORDEIRO, A. - A decisão segundo a equidade, O Direito, Ano 122. ${ }^{\circ}$, 1990-II; - Costume TUME, Enc. Polis, Vol. I, Lisboa, Verbo, 1983;

MENEZES CORDEIRO, A. - Direito das Obrigações, A. A. F. D. L., Lisboa, 1986;

MIMOSO, Maria João, - A justiça arbitral na composição dos litígios do comércio internacional. Tese de Mestrado [Texto policopiado], Lisboa, 1994;

MOLINEAUX, CH. - Moving toward a Construction Lex Mercatoria: A Lex Constructionis, Journal of International Arbitration, 1997;

MORÁN GARCÍA, M. E. - Derecho de los mercados financieros internacionales, Ed. Tirant lo Blanch,Valencia, 2002;

MUSTILL, Lord Justice - The New Lex Mercatoria: The First TwentyFive Years, em Liber Amicorum for the Rt. Hon. Lord Wilberforce, Pc, CMG, OBE, QC, Oxford, Clarendon Press, 1987;

OLIVEIRA ASCENÇÃO - O direito. introdução e teoria geral, 13. ${ }^{\text {a }}$ edição, Lisboa, 2005; - O Direito - Introdução e Teoria Geral Uma Perspetiva Luso- Brasileira, 9. ${ }^{a}$ edição revista, Coimbra, 
Almedina, 1995; - O direito. Introdução e teoria geral, Lisboa, Fundação Calouste Gulbenkian, 1978;

PAIS DE VASCONCELOS, Pedro - Contratos Atípicos. Coimbra, 1995

PAMBOUKIS, Ch, - La Lex mercatoria reconsidéré. Le droit internacional privé : esprit et méthodes. Melanges Paul Lagarde. Paris, Dalloz, 2005;

PAZ ARES, C. - Principio de eficiência y derecho privado, in Estudios en homenaje a M. Broseta Pont. Tirant lo Blanch, Valencia, 1995;

PESSOA JORGE - Direito das Obrigações: A.A.F.D.L., Lisboa, 1974;

PINA, C. COSTA - Conceito, Estrutura e Natureza dos Créditos

Documentários, págs. 111 e ss. In: "Estudos Jurídicose Económicos em Homenagem ao Professor Doutor João Lumbrales", págs. 95-117, Coimbra, Coimbra Editora, 2000;

PINA, C. Costa - Créditos Documentários - As regras e Usos Uniformes da Câmara de Comércio Internacional e a Prática Bancária, Coimbra, Coimbra Editora, 2000; - Créditos Documentários - As regras e Usos Uniformes da CCI e a prática Bancária, Coimbra, Coimbra Editora, 2000;

PIRES DE LIMA, F. A. / ANTUNES VARELA J. M., - Noções fundamentais de direito civil, Vol. I, Coimbra: Coimbra Editora, 4. ${ }^{\mathrm{a}}$ ed., 1957;

PRAENDL, F. - Measures od Damages in International Commercial Arbitration, in SJIL, 1987;

QUEIROZ, Everardo Nóbrega de - O princípio da razoabilidade na Nova Lex Mercatoria, Tese de Doutoramento, FFLCH-USP, 2000.

RECHSTEINER, Beat Walter. - A arbitragem privada internacional no Brasil. São Paulo, RT, 2001; - Direito internacional privado: teoria e prática. 6. ed. São Paulo, Saraiva, 2003; - Arbitragem privada internacional no Brasil: depois da nova lei 9.307, de 23.09.1996: Teoria e prática. 2. ${ }^{a}$ Ed., São Paulo, Revista dos Tribunais, 2001;

REHBINDE, Manfred, - Einführung in die rechtswissenschaft. 6 . $^{\text {a }}$ edição do manual de B. Rehfeldt, Berlim e Nova Iorque. 1988;

RIGAUX, F. - Pour una utre orde international, in BLANC, J. RIGAUX F., - Droit Économique II, Paris, Pedone, 1979 ;

ROBERT, J. - L'arbitrage - droit interne - droit international privé. 5. ${ }^{a}$ edição, Paris, Dalloz, 1983; 
SACARRERA, Guardiola, E. - La Compraventa Internacional: Importaciones y exportaciones. Barcelona: Bosch, Casa Editorial, S.A., 1994;

SANTOS JUSTO, A. - Introdução ao Estudo do Direito, Coimbra, Coimbra Editora, 6. ${ }^{\text {a Ed., 2012; }}$

SCHMITHOFF, C. - Das neue Recht des Welthandels, in Rabels Zeitschrift für ausländisches und internationals Privatrecht, 1964; The Law of International Trade, Ist Growth, Formulation and Operation, in The Sources of the Law of International Trade (With Special Reference to East-West Trade), Londres, Stevens \& Sons, 1964;

SERAGLINI, Christophe - Du bom usage des príncipes Unidroit dans l'arbitrage international, na Rev.Arb., 2003;

SIEHR, K, - Sachrecht im IPR, transnationales Recht und lex mercatoria, in W. Holl- U. Klinke, Internationales Privatrecht - Internationales Wirtschaftsrecht, Colónia/Berlim/Bona/Mogúncia, Carl Heymanns Verlag, 1985;

SOUSA SANTOS, B., O discurso e o poder - Ensaio sobre a sociologia da retórica jurídica, in Estudos em Homenagem ao Prof. Doutor J. J. Teixeira Ribeiro, II - IURIDICA, Coimbra, Faculdade de Direito, 1979;

STEIN Ursula - Lex Mercatoria. Realität und Theorie, Francofortesobre-o-Meno, 1995;

STRENGER, Irineu - Direito do Comércio Internacional e Lex Mercatoria. São Paulo, LTr., 1996;

UREBA, A. Alonso - Naturaleza y Régimen der Crédito Documentário, in: AAVV, " Contratos Bancários", Madrid, Civitas, 1992;

VERDERA Y TUELLS, E. - El 'Pierce the Veil, arbitral de Yves Derains. in RCEA, 1985 ;

VICENTE, Dário Moura - Da Arbitragem Comercial Internacional: Direito Aplicável ao mérito da causa, Coimbra Editora, 1990; Portugal e a Arbitragem Internacional, Janus, 2004;

VIRALLY, M. - Un tiers droit? Réflexions théoriques, in le droit des relations économiques internationales, in Études offertes à Berthold Goldman, Litec, Paris, 1987 ;

VRIES H. de, - Le caracteres normatif des pratiques commerciales internationales, in Hommage à Frédéric Eisemann, Paris, CCI, 1978 ; 
VV.AA. - Comentários a los Princípios de Unidroit para los Contratos del Comercio Internacional. Pamplona, Aranzadi, 2. edição, 2003.

Documentos eletrónicos:

GOODE, Roy - Communication on European Contract Law (reação à Comunicação da Comissão). Disponível em: http://europa.eu.int/comm/consumers/cons-int/ /safe-shop/fair-buspract/cont-law/comments/academics/index-en.htm

LANDO, O. - The Law Applicable to the Merits of the Dispute, in: SARCEVIC (ed.), Essays on International Commercial Arbitration. Boston, London, 1991, pág. 146. Disponível em http://tldb.unikoeln.de.

MENEZES CORDEIRO A. - Créditos Documentários. Revista OA > Ano 2007 > Ano 67 - Vol. I - Jan. 2007> Doutrina, Disponível em:

http://www.oa.pt/Conteudos/Artigos/detalhe_artigo.aspx?idc=3077 $7 \&$ idsc $=59032 \& i d a=59051$.

PEREIRA, Teresa Silva - Proposta de reflexão sobre um Código Civil Europeu, Artigos doutrinais da Ordem Dos Advogados, Publicações > Revista > Ano 2004 > Ano 64 - Vol. I / II - Nov. 2004.

Disponível em:http://www.oa.pt/Conteudos/Artigos/detalhe_artigo.aspx?idc=3 1559\&idsc $=45841 \&$ ida $=47182$;

RAPOSO, Mário - Temas de arbitragem comercial [Lex Mercatoria] ,Início> Publicações > Revista > Ano $2006>$ Ano 66 - Vol. I - Jan. $2006>$ Doutrina. Disponível em: http://www.oa.pt/Conteudos/Artigos/detalhe_artigo.aspx?idc=3155 9\&idsc $=47773 \&$ ida $=47824$

SZKLAROWKSY, Leon. - Arbitragem Marítima. In Revista Jurídica Consulex - Ano XII - n. ${ }^{\circ} 277$ - 31 de Julho de 2008. In passim Disponível em: http://www.2ccago.com.br/up/arbitragem.pdf.

TETLEY, William. - International Maritime and Admiralty Law. Québec: Éditions Yvon Blais, 2002.

The Bristol Corn \& Feed Trade Association. Disponível em: http://www.bcfta.org.uk/history.php.

Documentos Institucionais 
UNITED NATIONS ECONOMIC COMMISSION FOR EUROPE, Disponível em: http://www.UNECE.org/ceci/welcome.html,

COMISSÃO EUROPEIA - o Livro Verde sobre a viabilidade da introdução de obrigações de estabilidade. Bruxelas, 23-11-2011 COM (2011) 818 final.

UNIÃO EUROPEIA - As fontes não escritas do direito europeu: direito subsidiário, in EUROPA $>$ Sínteses da legislação da UE>Assuntos institucionais> Disponível em: http://eurlex.europa.eu/legalcontent/PT/TXT/HTML/?uri=URISERV:114533\&from=PT

UNCITRAL - "Nota explicativa da secretaria da UNCITRAL sobre a Convenção das Nações Unidas sobre contratos de compra e venda internacional de mercadorias.“ Disponível em: http://www.cisgbrasil.net/doc/explnotecisgtradamadeusorleans-final.pdf

Sites Institucionais

UNECE - Disponível em: http://www.unece.org/about-unece.html.

UNIDROIT - Disponível em: http://www.unidroit.org/aboutunidroit/membership

ICMA - Disponível em: http://www.icmagroup.org/. - História da ICMA.In International Capital Market Association - ICMA .Disponível em: http://www.icmagroup.org/AboutICMA/Organisation/history.aspx

ISDA Disponível em: http://www2.isda.org/

CCI - Disponível em: www.iccwbo.org; e http://www.icc-portugal.com/.

Jurisprudência Arbitral

CCI, n. ${ }^{\circ} 2404,1975$;

CCI, . 2438,1975 ;

CCI, n. ${ }^{\circ} 2443,1976$.

Jurisprudência nacional

Acórdão do Supremo Tribunal de Justiça, $1^{\text {a }}$ Secção, processo n. ${ }^{\circ}$ 406/09.0YFLSB, em 22-09-2009;

Acórdão do Supremo Tribunal de Justiça, processo n. ${ }^{\circ}$ 05A2507, em 1503-2005;

Acórdão do Supremo Tribunal de Justiça, processo n. ${ }^{\circ}$ 0636141, 11-012007;

Acórdão STJ de 16-07-1970, in: 198 BMJ, 1970. 